\title{
Bibliographical References
}

Adams (1971): James N. Adams, “A Type of Hyperbaton in Latin Prose”, in: PAPhS 17, 1-16.

Adler (2011): Eric Adler, “Cassius Dio’s Livia and the Conspiracy of Cinna Magnus”, in: GR\&BS

41, 133-154.

Agnes/Giacone Deangeli (1969): Leopoldo Agnes and Jolanda Giacone Deangeli, Velleio e

Floro, Torino.

Aigner (1972): Heribert Aigner, “M. Servilius Nonianus, cos. 35 n. Chr.: ein Servilius oder ein Nonius?", in: Historia 21, 507-512.

Aili (1979): Hans Aili, The Prose Rhythm of Sallust and Livy (Acta Universitatis Stockholmiensis 24), Stockholm.

Alfonsi (1975): Luigi Alfonsi, “Discussioni su letteratura storiografica 'inconnue”, in: StudUrb 49, 39-47.

Alonso-Núñez (1982): José Miguel Alonso-Núñez, The Ages of Rome, Amsterdam.

Ammirati (2010): Serena Ammirati, "Per una storia del libro latino antico. I papiri latini di contenuto letterario dal I sec. a.C. al I $\left.\right|^{\text {ex }} I^{\text {in. }}$ d.C.”, in: Scripta 3, 29-45.

Ammirati (2015): Serena Ammirati, Sul libro latino antico. Ricerche bibliologiche e paleografiche, Pisa.

Anderson (1962): Richard L. Anderson, The Rise and Fall of Middle Class Loyalty to the Roman

Empire: A Social Study of Velleius Paterculus and Ammianus Marcellinus, Berkeley (diss.).

André (1999): Jean-Marie André, “Les Sénèques et l’Espagne”, in: REL 77, 170-183.

Archambault (1966): Paul Archambault, "The Ages of Man and the Ages of the World. A Study of

Two Traditions", in: REAug 12, 193-228.

Aricò (1971): Giuseppe Aricò, “Nota lucanea”, in: Athenaeum 49, 70-73.

Armitage (2017): David Armitage, Civil Wars: A History in Ideas, New Haven.

Ash (1999): Rhiannon Ash, “An Exemplary Conflict: Tacitus' Parthian Battle Narrative (Annals 6.34-35)", in: Phoenix 53, 114-135.

Avenarius (1956): Gert Avenarius, Lukians Schrift zur Geschichtschreibung, Meisenheim am Glan.

Baar (1990): Manfred Baar, Das Bild des Kaisers Tiberius bei Tacitus, Sueton und Cassius Dio, Stuttgart.

Baier (1874): Gustav Baier, De Livio Lucani in carmine de bello civili auctore, Suidniciae (diss.). Baldwin (1983): Barry Baldwin, Suetonius, Amsterdam.

Baldwin (1998): Barry Baldwin, “Four Problems with Florus”, in: Latomus 47, 134-142.

Bardon (1940a): Henry Bardon, Le vocabulaire de la critique littéraire chez Sénèque le Rhéteur, Paris.

Bardon (1940b): Henry Bardon, Les Empereurs et les lettres latines d'Auguste à Hadrien, Paris.

Bardon (1943): Henry Bardon, “Mécanisme et stéréotypie dans le style de Sénèque le Rhéteur”, in: $A C 12,5-24$.

Bardon (1956): Henry Bardon, La littérature latine inconnue II. L'époque impériale, Paris.

Barnes (1984): Timothy D. Barnes, “The Composition of Cassius Dio's Roman History”, in:

Phoenix 38, 240-255.

Barnes (1998): Timothy D. Barnes, “Tacitus and the Senatus Consultum de Cn. Pisone Patre”, in: Phoenix 52, 125-148.

Barrett $\left(2015^{2}\right)$ : Anthony A. Barrett, Caligula: The Abuse of Power, New York. 
Bassi (1926): Domenico Bassi, “Papiri Ercolanesi Latini”, in: Aegyptus 7, 203-222.

Bayet/Baillet (1954): Jean Bayet and Gaston Baillet (eds), Tite-Live, Histoire romaine. Tome V, livre $V$, Paris.

Baynham (1998): Elizabeth Baynham, Alexander the Great: the Unique History of Quintus Curtius, Ann Arbor.

Beer (2009): Beate Beer, “Lukrez in Herkulaneum? - Beitrag zu einer Edition von PHerc. 395”, in: ZPE 168, 61-82.

Bellardi (1974): Giovanni Bellardi, “Gli ‘exitus illustrium virorum’ e il L. XVI degli Annali tacitiani”, in: $A \& R 19,129-137$.

Benario (1973): Herbert W. Benario, “The Text of Albinovanus Pedo”, in: Latomus 32, 166-169.

Benario (1975): Herbert W. Benario, An Introduction to Tacitus, Athens.

Bérard (1991): François Bérard, “Tacite et les inscriptions”, in: ANRW II 33.4, 3007-3050.

Berlan-Bajard (2018): Anne Berlan-Bajard, “Extrema litora mundi: quelques vers d’Albinovanus Pedo sur la découverte romaine des mers septentrionales (dans Sénèque le Rhéteur, Suasoires, 15)", in: Guillaume Flamerie de Lachapelle and Judith Rohman (eds), Lectures latines. 45 textes de la littérature latine interprétés par des professeurs. En hommage à Sylvie Franchet d'Espèrey, Bordeaux, 191-197.

Berno (2013): Francesca Romana Berno, “Eccellente ma non troppo: l'exemplum di Augusto in Seneca”, in: Mario Labate and Gianpiero Rosati (eds), La costruzione del mito augusteo, Heidelberg, 181-196.

Berti (2007): Emanuele Berti, Scholasticorum studia. Seneca il Vecchio e la cultura retorica e letteraria della prima età imperiale, Pisa.

Berti (2018): Emanuele Berti, Lo stile e l'uomo. Quattro epistole letterarie di Seneca (Sen. epist. 114; 40; 100; 84), Pisa.

Bessone (1978): Luigi Bessone, “Di alcuni errori di Floro”, in: RFIC 106, 421-431.

Bessone (1993a): Luigi Bessone, “Floro e le legazioni ecumeniche ad Augusto”, in: Athenaeum 84, 93-100.

Bessone (1993b): Luigi Bessone, "Floro un retore storico e poeta", in: ANRW II 34.1, 80-117.

Bessone (1995a): Luigi Bessone, “Biologismo e storiografia altoimperiale”, in: Patavium 3, 6587.

Bessone (1995b): Luigi Bessone, “Le età di Roma da Cicerone a Floro”, in: ACD 31, 11-19.

Bessone (1996): Luigi Bessone, La storia epitomata. Introduzione a Floro, Roma.

Bessone (2002-2003): Luigi Bessone, “Consulem ipse se fecit (Flor. 2, 13, 21). Considerazioni sul secondo consolato di Cesare", in: $A C D$ 38-39, 21-36.

Bessone (2004-2005): Luigi Bessone, “Ottaviano Augusto e il regno dei Caesares”, in: $A C D$ 40-41, 305-324.

Bessone (2008): Luigi Bessone, Senectus imperii. Biologismo e storia romana, Padova.

Biondi (2003): Giuseppe Gilberto Biondi, “'Laudatio' e ‘damnatio' di Nerone: l'aenigma' del proemio lucaneo”, in: Gualandri/Mazzoli (2003), 265-275.

Blank/Longo Auricchio (2004): David Blank and Francesca Longo Auricchio, “An Inventory of the Herculaneum Papyri from Piaggio's Time”, in: CErc 30, 131-147.

Bocciolini Palagi (1978): Laura Bocciolini Palagi, “Genesi e sviluppo della questione dei due Seneca nella tarda latinità”, in: SIFC 50, 215-231.

Bonamente/Segoloni (1987): Giorgio Bonamente and Maria Paola Segoloni (eds), Germanico: La persona, la personalità, il personaggio nel bimillenario della nascita, Roma.

Bongi (1949): Vincenzo Bongi, “Nuova esegesi del frgm. di Albinovano Pedone”, in: RIL 82, 2848. 
Bonner (1949): Stanley F. Bonner, Roman Declamation in the Late Republic and Early Empire, Liverpool.

Bonner (1966): Stanley F. Bonner, “Lucan and the Declamation Schools”, in: AJPh 87, 257-289 [repr. in: Tesoriero (2010), 69-106].

Borgo (2012): Antonella Borgo, “Res nova et inusitata, supplicium de studiis sumi (Sen. contr. 10, praef. 5)”, in: Paideia 67, 33-53.

Bornecque (1902a): Henry Bornecque, Les déclamations et les déclamateurs d'après Sénèque le Père, Lille.

Bornecque (1902b): Henry Bornecque (ed.), Sénèque le Rhéteur, Controverses et Suasoires, Paris.

Bornecque (1907): Henry Bornecque, Les clausules métriques latines, Lille.

Bosworth (1977): Albert Brian Bosworth, "Tacitus and Asinius Gallus", in: AJAH 2, 173-192.

Bravo (2007): Benedetto Bravo, “Antiquarianism and History”, in: John Marincola (ed.), A Companion to Greek and Roman Historiography, Malden, 515-527.

Breed et all. (2010): Brian W. Breed, Cynthia Damon \& Andreola Rossi (eds), Citizens of Discord: Rome and its Civil Wars, New York.

Briquel (1988): Dominique Briquel, “Claude érudit et empereur”, in: CRAI 1, 217-232.

Brisset (1964): Jacqueline Brisset, Les idées politiques de Lucain, Paris.

Brodersen (1991): Kai Brodersen (ed.), Appians Antiochike (Syriake 1,1-44,232), München.

Brodersen (1993): Kai Brodersen, “Appian und sein Werk”, in: ANRW II 34.1, 341-363.

Broughton (1952): Thomas R.S. Broughton, The Magistrates of the Roman Republic II, New York. Brunhölzl (1998): Franz Brunhölzl, “Der sogenannten Carmen de bello Actiaco (P.Herc. 817)”, in: CodMan 22, 3-10.

Brünnert (1888): Gustav Brünnert, Sallustius und Dictys Cretensis (Programm des K. Gymnasiums zu Erfurt), Erfurt.

Brunt (1988): Peter Brunt, The Fall of the Roman Republic and Other Essays, Oxford.

Bucher (2000): Gregory Bucher, “The Origins, Program and Composition of Appian's Roman History", in: TAPhA 130, 411-458.

Buongiorno (2016): Pierangelo Buongiorno, "Senatus consulta: struttura, formulazioni linguistiche, tecniche (189 a.C.-138 d.C.)”, in: AUPA 59, 17-60.

Burden-Strevens/Lindholmer (2018): Christopher Burden-Strevens and Mads Lindholmer (eds), Cassius Dio's Forgotten History of Early Rome: The Roman History, Books 1-21, Leiden/ Boston.

Burgess/Kulikowski (2013): Robert W. Burgess and Michael Kulikowski, Mosaics of Time, Turnhout.

Busolt (1890): Georg Busolt, “Quellenkritische Beiträge zur Geschichte der römischen Revolutionszeit”, in: JKPh 141, 321-349, 405-438.

Byrne (1999): Shannon Byrne, "Pointed Allusions. Maecenas and Sallustius in the Annals of Tacitus", in: RhM 142, 339-345.

Caballos et all. (1996): Antonio Caballos, Werner Eck and Fernando Fernández (eds), El senadoconsulto de Gneo Pisón padre, Sevilla.

Campiche (1965): Émile Campiche, “Les causes de la guerre civile d’après Lucain (Pharsale, 1 , 67-182)”, in: EL II 8, 224-231.

Canfora (1993): Luciano Canfora, Studi di storia della storiografia romana, Bari.

Canfora (2000): Luciano Canfora, “Seneca e le guerre civili”, in: Parroni (2000), 161-177.

Canfora (2015): Luciano Canfora, Augusto figlio di Dio, Roma/Bari. 
Capasso (2003): Mario Capasso, “Filodemo e Lucrezio: due intellettuali nel patriai tempus iniquum”, in: Annick Monet (ed.), Le Jardin Romain. Épicurisme et poésie à Rome. Mélanges offerts à Mayotte Bollack, Lille, 77-107.

Capasso (2007): Mario Capasso, "I rotoli ercolanesi: da libri a carboni e da carboni a libri”, in: Bernhard Palme (ed.), Akten des 23. Internationalen Papyrologenkongresses, Wien, 7377.

Capasso (2011): Mario Capasso, Les papyrus latins d'Herculanum. Découverte, consistence, contenu, Liège.

Capasso (2013a): Mario Capasso, “Libri greci e libri latini nella Villa ercolanese dei papiri: un rapporto problematico?”, in: Scripta 6, 35-40.

Capasso (2013b): Mario Capasso, "Del cattivo e del pessimo uso dei disegni dei Papiri Ercolanesi”, in: PapLup 22, 44-60.

Capasso/Radiciotti (1999): Mario Capasso and Paolo Radiciotti, “La falsa falsificazione del De bello Actiaco (PHerc. 817). A proposito di un paradosso ercolanese”, in: PapLup 8, 117135.

Cape (1997): Robert W. Cape, “Persuarsive History: Roman Rhetoric and Historiography”, in: William J. Dominik (ed.), Roman Eloquence: Rhetoric in Society and Literature, London, 211-228.

Carsana (2018): Chiara Carsana, “Asinio Pollione e Seneca padre nel libro 2 delle Guerre Civili di Appiano", in: Devillers/Sebastiani (2018), 269-279.

Casamento (2002): Alfredo Casamento, "Sen. contr. 2,1,10: una narratio del retore Fabiano fra suggestioni letterarie ed echi tragici", in: Pan 20, 117-132.

Castagna (2003): Luigi Castagna, "Lucano e Seneca: limiti di una aemulatio", in: Gualandri/ Mazzoli (2003), 277-290.

Castiglioni (1928): Luigi Castiglioni, “Lattanzio e le storie di Seneca padre”, in: RFIC 56, 454475.

CatPErc (1979): Marcello Gigante (ed.), Catalogo dei Papiri Ercolanesi, Napoli.

Cavallo (1983): Guglielmo Cavallo, Libri scritture scribi a Ercolano, Napoli.

Cavallo (1984): Guglielmo Cavallo, “I rotoli di Ercolano come prodotti scritti. Quattro riflessioni”, in: $S \& C$ 8, 5-30.

Cavallo (1989): Guglielmo Cavallo, “Libro e cultura scritta”, in: Emilio Gabba and Aldo Schiavone (eds), Storia di Roma, IV: Caratteri e morfologie, Torino, 693-734.

Cavallo (2005): Guglielmo Cavallo, Il calamo e il papiro. La scrittura greca dall'età ellenistica ai primi secoli di Bisanzio, Firenze.

Cavallo (2013): Guglielmo Cavallo, “La papirologia letteraria tra bibliologia e paleografia: un consuntivo del passato e uno sguardo verso il futuro", in: JJP 43, 277-312.

Cavallo (2015): Guglielmo Cavallo, “I papiri di Ercolano come documenti per la storia delle biblioteche e dei libri antichi”, in: MAL 35, 573-598.

Cavallo/Fioretti (2014): Guglielmo Cavallo and Paolo Fioretti, “Chiaroscuro. Oltre l'angolo di scrittura (secoli I a.C.-VI d.C.)", in: Scripta 7, 29-64.

Champlin (2003): Edward Champlin, Nero, Cambridge/London.

Champlin (2008): Edward Champlin, "Tiberius the Wise", in: Historia 57, 408-425.

Champlin (2011): Edward Champlin, “Sex on Capri”, in: TAPhA 141, 315-332.

Chiron (1993): Pierre Chiron (ed.), Démétrios. Du Style, Paris.

Cichorius (1922): Conrad Cichorius, Römische Studien, Leipzig.

Citroni Marchetti (1991): Sandra Citroni Marchetti, Plinio il Vecchio e la tradizione del moralismo romano, Pisa. 
Citti (2005): Francesco Citti, “Elementi biografici nelle ‘Prefazioni’ di Seneca il Vecchio”, in: Hagiographica 12, 171-222.

Cizek (1995): Eugen Cizek, Histoire et historiens à Rome dans l'Antiquité, Lyon.

Cizek (2002): Eugen Cizek, “À propos de la lettre 100 de Sénèque”, in: Latomus 61, 388-397.

Clarke (1999): Katherine Clarke, Between Geography and History: Hellenistic Constructions of the Roman World, Oxford.

Clausen (1947): Wendell Clausen, “Notes on Sallust's Histories”, in: AJPh 68, 293-301.

CLTP: Maria Chiara Scappaticcio (ed.), Corpus of Latin Texts on Papyrus, Cambridge (forthcoming).

Cogitore (2011): Isabelle Cogitore, Le doux nom de liberté: histoire d'une idée politique dans la Rome antique, Bordeaux/Paris.

Cogitore (2012): Isabelle Cogitore, “Les exemples historiques dans les Lettres à Lucilius”, in: François Guillaumont and Patrick Laurence (eds), La présence de l'histoire dans l'épistolaire, Tours, 193-212.

Cogitore (2016): Isabelle Cogitore, "Du Vengeur de César au Prince de la Paix, une longue métamorphose", in: Sabine Luciani (ed.), Entre mots et marbre. Les métamorphoses d'Auguste, Bordeaux, 195-208.

Cordier (1943): André Cordier, review of Bardon (1940a), in: RPh 17, 220-222.

Costa (2013): Stefano Costa, Quod olim fuerat. La rappresentazione del passato in Seneca prosatore, Zürich/New York.

Costabile (1984): Felice Costabile, “Opere di oratoria politica e giudiziaria nella biblioteca della Villa dei Papiri: i PHerc. latini 1067 e 1475”, in: Atti del XVII Congresso internazionale di Papirologia II, Napoli, 591-606.

Coudry (1994): Marianne Coudry, "Sénatus-consultes et acta senatus: rédaction, conservation et archivage des documents émanant du Sénat, de l'époque de César à celle des Sévères", in: Ségolène Demougin (ed.), La Mémoire perdue. À la recherche des archives oubliées, publiques et privées, de la Rome antique, Paris, 65-102.

Cowan (2011): Eleanor Cowan (ed.), Velleius Paterculus: Making History, Swansea.

Crönert (1900): Wilhelm Crönert, "Über die Erhaltung und Behandlung der herkulanensischen Rollen”, in: NJKIA 3, 586-591.

Crönert (1975): Wilhelm Crönert, Studi Ercolanesi, Napoli.

Cuff (1967): Peter Cuff, “Prolegomena to a Critical Edition of Appian, B.C. I”, in: Historia 16, 177-188.

Cupaiuolo (1984): Fabio Cupaiuolo, “Caso, fato e fortuna negli storici latini”, in: BStudLat 14, 3-38.

D'Alton (1931): John F. D’Alton, Roman Literary Theory and Criticism, London.

D’Anna (1995): Giovanni D’Anna, “L'opera di Tacito nella storiografia latina dell'impero", in:

Storia, letteratura e arte nel secondo secolo dopo Cristo: atti del convegno, Mantova, 8-910 ottobre 1992, Firenze, 43-59.

D’Anna (1998): Giovanni D'Anna, “Ancora sul giudizio tacitiano di Seneca”, in: RCCM 40, 77-83.

Damon (2003): Cynthia Damon (ed.), Tacitus. Histories. Book I, Cambridge.

Damon (2014): Cynthia Damon, “Suetonius the ventriloquist”, in: Power/Gibson (2014), 38-57.

Damon/Takács (1999): Cynthia Damon and Sarolta Takács (eds), "The Senatus Consultum de Cn. Pisone Patre", in: AJPh 120.1, Chicago, VII-IX.

Damschen/Heil (2012): Gregor Damschen and Andrea Heil (eds), Brill's Companion to Seneca: Philosopher and Dramatist, Leiden/Boston. 
Danesi Marioni (2003): Giulia Danesi Marioni, “Il tragico scenario delle guerre civili nella prima Controversia di Seneca Retore", in: Prometheus 29, 151-170.

Danesi Marioni (2006): Giulia Danesi Marioni, “L’eloquenza violata. Considerazioni intorno alla prima prefazione dell'opera di Seneca Retore”, in: Carlo Santini, Loriano Zurli and Luca Cardinali (eds), Concentus ex dissonis. Scritti in onore di Aldo Setaioli I, Perugia, 253-268.

De Coninck (1983): Luc De Coninck, Suetonius en de Archivalia, Brussels.

Degrassi (1963): Attilio Degrassi (ed.), Inscriptiones Italiae: Fasti et elogia XIII, Roma.

de la Ville de Mirmont (1910-1913): Henri de la Ville de Mirmont, "Les déclamateurs espagnols aux temps d'Auguste et de Tibère”, in: BH 12 (1910) 1-22; 14 (1912) 11-29; 229-243; 341352; 15 (1913) 154-169; 237-263; 384-410.

Del Giovane (2015): Barbara Del Giovane, Seneca, la diatriba e la ricerca di una morale austera. Caratteristiche, influenze, mediazioni di un rapporto complesso, Firenze.

Del Mastro (2005): Gianluca Del Mastro, “Riflessioni sui papiri latini ercolanesi”, in: CErc 35, 183-194.

Del Mastro (2010): Gianluca Del Mastro, “Papiri ercolanesi vergati da più mani”, in: S\&T 8, 3-66.

Del Mastro (2011): Gianluca Del Mastro, "Filosofi, scribi e glutinatores. I rotoli della Villa dei papiri di Ercolano”, in: Lucio Del Corso and Paolo Pecere (eds), Il libro filosofico dall'antichità al XXI secolo (Quaestio 11), 35-64.

Del Mastro (2014): Gianluca Del Mastro, Titoli e annotazioni bibliologiche nei papiri greci di Ercolano, Napoli.

Del Mastro (2018): Gianluca Del Mastro, “I papiri ritrovati a Pompei: qualche aggiornamento”, in: PapLup 27, 37-43.

Demandt (1965): Alexander Demandt, Zeitkritik und Geschichtsbild im Werk Ammians, Bonn.

Demougin (1988): Ségolène Demougin, L'ordre équestre sous les Julio-Claudiens, Roma.

De Oliveira (1992): Francisco De Oliveira, Les idées politiques et morales de Pline l'Ancien, Coimbra.

De Stefani (1910): Edoardo L. De Stefani, “De Vellei Paterculi periodis”, in: SIFC 18, 19-31.

Devillers (1994): Olivier Devillers, L'art de la persuasion dans les Annales de Tacite, Bruxelles.

Devillers (1999): Olivier Devillers, "Le récit de la conjuration de Pison dans les Annales de Tacite (XV 48-74): quelques aspects”, in: Jean-Michel Croisille, René Martin and Yves Perrin (eds), Neronia V. Néron I: histoire et légende, Bruxelles, 45-65.

Devillers (2003a): Olivier Devillers, Tacite et les sources des Annales. Enquêtes sur la méthode historique, Louvain/Paris/Dudley.

Devillers (2003b): Olivier Devillers, “La composante biographique dans l'historiographie impériale avant Tacite”, in: Guy Lachenaud and Dominique Longrée (eds), Grecs et Romains aux prises avec l'histoire. Représentations, récits et idéologie. Colloque de Nantes et Angers II, Rennes, 609-619.

Devillers (2016a): Olivier Devillers, “Allusions au dossier documentaire et caractérisation des empereurs dans les Annales de Tacite", in: RAEL 2, 37-48.

Devillers (2016b): Olivier Devillers, “Cassius Dion et l'évolution de l'annalistique. Remarques à propos de la représentation des Julio-Claudiens dans l'Histoire romaine", in: Fromentin et all (2016), 317-334.

Devillers/Sebastiani (2018): Olivier Devillers and Breno Battistin Sebastiani (eds), Sources et modèles de historiens anciens, Bordeaux.

De Vivo (1980): Arturo De Vivo, Tacito e Claudio. Storia e codificazione letteraria, Torino.

De Vivo (1998): Arturo De Vivo, Costruire la memoria. Ricerche sugli storici latini, Napoli. 
De Vivo (2003): Arturo De Vivo, “Le parole ambigue della storia. La morte di Germanico negli Annales di Tacito", in: Valeria Viparelli (ed.), Tra strategie retoriche e generi letterari. Dieci studi di letteratura latina, Napoli, 69-102.

De Vivo (2012): Arturo De Vivo, "Seneca e i terremoti (Questioni naturali, libro VI)", in: Marco Beretta, Francesco Citti and Lucia Pasetti (eds), Seneca e le scienze naturali, Firenze, 93106.

Dorandi (2000): Tiziano Dorandi, Le stylet et la tablette. Dans le secret des auteurs antiques, Paris.

Dorandi (2017a): Tiziano Dorandi, “La nuova cronologia della 'Villa dei Papiri' a Ercolano e le sorti della biblioteca di Filodemo", in: WJ 41, 183-203.

Dorandi (2017b): Tiziano Dorandi, “L'archivio di Robert Marichal o la paleografia quale scienza dello spirito", in: Scappaticcio (2017), 17-26.

Drummond (2013): Andrew Drummond, “56. C. Asinius Pollio: Introduction”, in: FRHist I, 430445.

Duchêne (2014): Pauline Duchêne, Écrire sur les premiers empereurs: l'élaboration du récit chez Tacite et Suétone, Paris (diss.).

Duchêne (2018): Pauline Duchêne, "Sources et composition narrative dans les récits de la mort d'Othon", in: Devillers/Sebastiani (2018), 247-258.

Duff (1927): John Wight Duff, A Literary History of Rome in the Silver Age, London.

Du Four (1941): Mary Johnstone Du Four (ed.), C. Suetonii Tranquilli vita Tiberii, Chapters I to XXIII, Philadelphia.

Duret (1986): Luc Duret, “Dans l'ombre des plus grands. Poètes et prosateurs mal connus de l'époque augustéenne”, in: ANRW II 30.3, 1447-1560.

Dutoit (1936): Ernest Dutoit, “Le thème de 'la force qui se détruit elle-même' (Hor. Epod. 16, 2) et ses variations chez quelques auteurs latins", in: REL 14, 365-373.

Earl (1961): Donald C. Earl, The Political Thought of Sallust, Cambridge.

Eck et all. (1996): Werner Eck, Antonio Caballos and Fernando Fernández (eds), Das Senatus Consultum de Cn. Pisone Patre, München.

Edward (1928): William A. Edward (ed.), The Suasoriae of Seneca the Elder, Cambridge.

Elefante (1999): Maria Elefante (ed.), Velleio Patercolo: $i$ due libri al console Marco Vinicio, Napoli.

Emberger (2005): Peter Emberger, Catilina und Caesar. Ein historisch-philologischer Kommentar zu Florus (epit. 2,12-13), Hamburg.

Ernout (19646): Alfred Ernout (ed.), Salluste. Catilina; Jugurtha; Fragments des histoires, Paris. Essler (2019): Holger Essler, “PHerc. 1475: ein Commentarius”, in: CErc 49, 135-162.

Fabia (1891): Philippe Fabia, Les sources de Tacite dans les Histoires et les Annales, Paris.

Facchini Tosi (1990): Claudia Facchini Tosi, Il proemio di Floro. La struttura concettuale e formale, Bologna.

Facchini Tosi (1998): Claudia Facchini Tosi (ed.), Anneo Floro, Storia di Roma. La prima e la seconda età, Bologna.

Faider (1921): Paul Faider, Études sur Sénèque, Gand.

Fairweather (1981): Janet Fairweather, Seneca the Elder, Cambridge.

Fairweather (1984): Janet Fairweather, “The Elder Seneca and Declamation”, in: ANRW II 32.1, 514-556.

Feddern (2013): Stefan Feddern, Die Suasorien des älteren Seneca: Einleitung, Text und Kommentar, Berlin/Boston.

Ferrill (1964): Arther L. Ferrill, Seneca: The Rise to Power, Ann Arbor (diss.). 
Fioretti (2014): Paolo Fioretti, “Sulla genesi della capitale romana 'rustica”, in: S\&T12, 29-76. Fioretti (2016): Paolo Fioretti, "Percorsi di autori latini tra libro e testo. Contesti di produzione e di ricezione in epoca antica”, in: $S \& T 14,1-38$.

Flach (1973a): Dieter Flach, Tacitus in der Tradition der antiken Geschichtsschreibung, Göttingen.

Flach (1973b): Dieter Flach, “Tacitus und seine Quellen in den Annalenbüchern I-Vl”, in: Athenaeum 61, 92-108.

Flach (1973c): Dieter Flach, "Die taciteische Quellenbehandlung in den Annalenbüchern XIXVI”, in: $M H$ 30, 88-103.

Flach (1985): Dieter Flach, Einführung in die römische Geschichtsschreibung, Darmstadt.

Fleskes (1914): Wilhelm Fleskes, Vermischte Beiträge zum literarischen Porträt des Tyrannen im Anschluß an die Deklamationen, Bonn (diss.).

Flower (1999): Harriet I. Flower, "Piso in Chicago: A Commentary on the APA/AIA Joint Seminar on the Senatus Consultum de Cn. Pisone Patre”, in: Damon/Takács (1999), 99-115.

Flower (2010): Harriet I. Flower, “Rome’s First Civil War and the Fragility of Republican Political Culture”, in: Breed et all. (2010), 73-86.

Fohlen (1979): Jeannine Fohlen, “Recherches sur le manuscrit palimpseste Vatican, Pal. lat. 24", in: S\&C 3, 195-222.

Forbes (1936): Clarence Forbes, “Books for the Burning”, in: TAPhA 67, 114-125.

Formicola (2013): Crescenzo Formicola (ed.), Il libro quarto degli Annales, Napoli.

Forster (1929): Edward S. Forster (ed.), Florus, London.

Forster (1949): Edward S. Forster, “Florus”, in: Oxford Classical Dictionary, Oxford, 365.

Franco (2007): Carlo Franco, “Dal documento al racconto: i libri claudiani”, in: Maria Antonietta Giua (ed.), Ripensando Tacito (e Ronald Syme). Storia e storiografia, Pisa, 99-116.

Freund (2009): Stefan Freund (ed.), Laktanz, Divinae institutiones, Buch 7: De vita beata. Einleitung, Text, Übersetzung und Kommentar, Berlin/New York.

FRHist I: Timothy J. Cornell (ed.), The Fragments of the Roman Historians I, Oxford 2013. FRHist II: Timothy J. Cornell (ed.), The Fragments of the Roman Historians II, Oxford 2013. FRHist III: Timothy J. Cornell (ed.), The Fragments of the Roman Historians III, Oxford 2013. Frick (1888): Carolus Frick (ed.), Pomponii Melae de chorographia libri tres, Leipzig.

Friedländer (1862): Ludwig Friedlaender, Darstellungen aus der Sittengeschichte Roms. In der Zeit von Augustus bis zum Ausgang der Antonine IV, Leipzig.

Friedländer (1886): Ludwig Friedländer (ed.), M. Valerii Martialis Epigrammaton Libri, Leipzig. Friggeri et all. (2012): Rosanna Friggeri, Maria Grazia Granino Cerere and Gian Luca Gregori (eds), Terme di Diocleziano: la collezione epigrafica, Milano.

Fromentin et all. (2016): Valérie Fromentin, Estelle Bertrand, Michèle Coltelloni-Trannoy, Michel Molin and Gianpaolo Urso (eds), Cassius Dion: nouvelles lectures, Bordeaux. Fukuyama (1992): Francis Fukuyama, The End of History and the Last Man, New York.

Furneaux (1896): Henry Furneaux (ed.), The Annals of Tacitus, Oxford.

Furneaux (1907²): Henry Furneaux (ed.), The Annals of Tacitus, Oxford.

Gabba (1956): Emilio Gabba, Appiano e la storia delle guerre civili, Firenze.

Gabba (1984): Emilio Gabba, "The Historians and Augustus", in: Fergus Millar and Erich Segal (eds), Caesar Augustus: Seven Aspects, Oxford, 61-88.

Galdi (2009): Giovanbattista Galdi, “Der Lebensaltervergleich: neue Beobachtungen zu einem alten Bild", in: Hermes 137, 403-424.

Galimberti (2001): Alessandro Galimberti, I Giulio-Claudi in Flavio Giuseppe (Al 18.-20.), Alessandria. 
Galinsky (1996): Karl Galinsky, Augustan Culture, Princeton.

Galtier (2008): Fabrice Galtier, "Lettres, regard et pouvoir dans la première hexade des Annales de Tacite", in: Patrick Laurence and François Guillaumont (eds), Epistulae antiquae $V$. Actes du Ve colloque international "L'épistolaire antique et ses prolongements européens" (Université François-Rabelais, Tours, 6-7-8 décembre 2006), Leuven, 177-186.

Garbarino (2003): Giovanna Garbarino (ed.), Philosophorum Romanorum fragmenta usque ad L. Annaei Senecae aetatem, Bologna.

Garbarino (2006): Giovanna Garbarino, "Lo stile del filosofo secondo Seneca: una rilettura dell'epistola 100”, in: Fabio Gasti (ed.), Il latino dei filosofi a Roma antica. Atti della V Giornata ghisleriana di filologia classica, Pavia 12-13 aprile 2005, Pavia, 57-74.

Garzetti (1964): Albino Garzetti, “Floro e l'età adrianea”, in: Athenaeum 42, 136-156.

Gascou (1984): Jacques Gascou, Suétone historien, Paris.

Gelzer (1957): Matthias Gelzer, review of Piero Meloni, Il valore storico e le fonti del libro Macedonico di Appiano, in: BO 14, 55-57 (repr. in: Kleine Schriften, Wiesbaden 1964, 280-285).

Giancotti (1957): Francesco Giancotti, Cronologia dei Dialoghi di Seneca, Torino.

Gigante (1991): Marcello Gigante, "Virgilio e i suoi amici tra Napoli e Ercolano", in: AVM 59, $87-125$.

Gigante (1998): Marcello Gigante, Altre ricerche filodemee, Napoli.

Gigante/Capasso (1989): Marcello Gigante and Mario Capasso, “Il ritorno di Virgilio a Ercolano", in: SIFC 7, 3-6.

Ginsberg (2013): Lauren D. Ginsberg, “Wars More than Civil: Memories of Pompey and Caesar in the "Octavia"', in: AJPh 134, 637-674.

Giua (1975): Maria Antonietta Giua, "Tiberio simulatore nella tradizione storica pretacitiana”, in: Athenaeum 63, 352-363.

Giua (1998): Maria Antonietta Giua, "Sul significato dei 'rumores' nella storiografia di Tacito", in: $R S / 110,38-59$.

Giua (2000): Maria Antonietta Giua, "Tra storiografia e comunicazione ufficiale”, in: Athenaeum 88, 253-275.

Gloyn (2017): Liz Gloyn, The Ethics of the Family in Seneca, Cambridge.

Goodyear (1972): Francis R.D. Goodyear (ed.), The Annals of Tacitus. Books 1-6I (Annals 1.154), Cambridge.

Goodyear (1981): Francis R.D. Goodyear (ed.), The Annals of Tacitus. Books 1-6 II (Annals 1.5581 and Annals 2), Cambridge.

Goukowsky (2007): Paul Goukowsky (ed.), Appien, Histoire Romaine, Tome VI, Livre XI, Le livre Syriaque, Paris.

Goukowsky (2014): Paul Goukowsky (ed.), Diodore de Sicile, Bibliothèque Historique, Fragments, Tome IV, Livre XXXIII-XL, Paris.

Goukowsky (2016): Paul Goukowsky, “Appien entre empire et guerre civile”, in: Histos 10, ClCX.

Gowing (1990): Alain M. Gowing, “Tacitus and the Client Kings”, in: TAPhA 120, 315-331.

Gowing (1992): Alain M. Gowing, The Triumviral Narratives of Appian and Cassius Dio, Ann Arbor.

Griffin (1972): Miriam T. Griffin, “The Elder Seneca and Spain”, in: JRS 62, 1-19.

Griffin (1976): Miriam T. Griffin, Seneca: A Philosopher in Politics, Oxford.

Griffin (1992): Miriam T. Griffin, Seneca: A Philosopher in Politics, Oxford (repr. with a postscript).

Grisart (1961): Albert Grisart, “Suétone et les deux Sénèque”, in: Helikon 1, 302-308. 
Gualandri/Mazzoli (2003): Isabella Gualandri and Giancarlo Mazzoli (eds), Gli Annei: una famiglia nella storia e nella cultura di Roma imperiale: atti del convegno internazionale di Milano-Pavia, 2-6 maggio 2000, Como.

Guastella (1999): Gianni Guastella (ed.), Gaio Svetonio Tranquillo. L'imperatore Claudio (Vite dei Cesari V), Venezia.

Gudeman (1894): Alfred Gudeman (ed.), Dialogus de Oratoribus, Boston.

Guérin (2009): Charles Guérin, “La personne oratoire entre rhétorique, biographie et histoire. Le cas des Controuersiae de Sénèque le Rhéteur”, in: Interférences 5 [http:/interferences.revues.org/897; DOI: 10.400/interférences.897].

Guérin (2012-2013): Charles Guérin, “Intempestiva philosophia? Éloquence déclamatoire et éloquence philosophique au $\mathrm{I}^{\text {er }}$ siècle ap. J.-C.”, in: Ítaca 28-29, 21-43.

Guidobaldi/Esposito (2009): Maria Paola Guidobaldi and Domenico Esposito, “Le nuove ricerche archeologiche nella Villa dei Papiri a Ercolano”, in: CErc 39, 331-370.

Guidobaldi/Esposito (2010): Maria Paola Guidobaldi and Domenico Esposito, “New Archaeological Research at the Villa of the Papyri in Herculaneum", in: Mantha Zarmakoupi (ed.), The Villa of the Papyri at Herculaneum. Archaeology, Reception, and Digital Reconstruction, Berlin/New York, 21-61.

Guttilla (1972-1973): Giuseppe Guttila, “La morte di Cremuzio Cordo nella Consolatio ad Marciam. Appunti per una storia degli exitus”, in: ALGP 9-10, 153-179.

Haase (1837): Friederich Haase, review of publications on Velleius Paterculus, in: Allgemeine Literatur-Zeitung 100-104, coll. 189-224.

Haase (1898-1907): Friederich Haase (ed.), L. Annaei Senecae opera quae supersunt I-III, Leipzig.

Habinek (2013): Thomas Habinek, “Imago suae vitae: Seneca’s Life and Career”, in: Damschen/Heil (2012), 3-31.

Hahn (1933): Eleonore Hahn, Die Exkurse in den Annalen des Tacitus, München.

Hahn (1964): István Hahn, “Appien et le cercle de Sénèque”, in: AAntHung 12, 169-206.

Hahn (1965): István Hahn, “Prooemium und Disposition der Epitome des Florus”, in: Eirene 4, 21-38.

Hahn (1982): István Hahn, “Appian und seine Quellen”, in: Gerhard Wirth (ed.), RomanitasChristianitas: Untersuchungen zur Geschichte und Literatur der römischen Kaiserzeit, Berlin, 251-276.

Håkanson (1989): Lennart Håkanson (ed.), L. Annaeus Seneca Maior, Oratorum et rhetorum sententiae divisiones colores, Leipzig.

Håkanson (2016): Lennart Håkanson, Unveröffentlichte Schriften. Band 2: Kommentar zu Seneca Maior, Controversiae, Buch I, Berlin/Boston.

Hamblenne (1985): Pierre Hamblenne, “Une interprétation de decoxit (Flor. praef. 8)", in: Latomus 44, 623-626.

Hannak (1869): Emanuel Hannak, Appianus und seine Quellen, Wien.

Härtke (1951): Werner Härtke, Römische Kinderkaiser. Eine Strukturanalyse römischen Denkens und Daseins, Berlin.

Hau (2009): Lisa Hau, "The Burden of Good Fortune in Diodorus Siculus: A Case for Originality?", in: Historia 58, 171-197.

Hau et all. (2018): Lisa Hau, Alexander Meeus and Brian Sheridan (eds), Diodoros of Sicily: Historiographical Theory and Practice in the Bibliotheke, Leuven.

Häussler (1964): Reinhard Häussler, “Vom Ursprung und Wandel des Lebensaltervergleichs”, in: Hermes 92, 313-341. 
Häussler (1983): Reinhard Häussler, “Neues zum spätrömischen Lebensaltervergleich”, in: János Harmatta (ed.), Proceedings of the VIIth Congress of the International Federation of the Societies of Classical Studies, Budapest, 183-191.

Havas (1983): László Havas, “La conception organique de l'histoire sous l'Empire romain et ses origines", in: $A C D$ 19, 99-106.

Havas (1994): László Havas, “Il ritratto di Augusto nella storiografia in lingua latina del primo periodo Antonino", in: AAASZeged 26, 21-29.

Havas (1997): László Havas (ed.), P. Annii Flori Opera quae extant omnia, Debrecini.

Heldmann (1982): Konrad Heldmann, Antike Theorien über Entwicklung und Verfall der Redekunst, München.

Heldmann (1987): Konrad Heldmann, “Livius über Monarchie und Freiheit und der römische Lebensaltervergleich", in: WJA 13, 209-230.

Hellegouarc'h (1982): Joseph Hellegouarc'h (ed.), Velleius Paterculus: Histoire Romaine, Paris.

Henderson (1963): Isabel M. Henderson, “The Establishment of the equester ordo", in: JRS 53, 61-72.

Hinard (2008): François Hinard, “Introduction générale” and “Notice”, in: Paul Goukowsky and François Hinard (eds), Appien, Histoire Romaine, Livre XIII: Guerres civiles Livre I, Paris, VII-CCXLIV.

Hirschfeld (1899): Otto Hirschfeld, “Anlage und Abfassungszeit der Epitome des Florus”, in: SAWDDR 29, 541-554 (repr. in: Kleine Schriften, Berlin 1913, 867-880).

Hofmann-Löbl (1996): Iris Hofmann-Löbl, Die Calpurnii. Politisches Wirken und familiäre Kontinuität, Frankfurt.

den Hollander (2011): William den Hollander, Josephus, the Emperors, and the City of Rome: from Hostage to Historian, Leiden.

Horstkotte (1989): Hermann-Joseph Horstkotte, “Die 'Mordopfer' in Senecas Apocolocyntosis”, in: ZPE 77, 113-143.

Hose (1994): Martin Hose, Erneuerung der Vergangenheit. Die Historiker im Imperium Romanum von Florus bis Cassius Dio, Stuttgart/Leipzig.

Hose (2007): Martin Hose, “Cassius Dio: A Senator and Historian in the Age of Anxiety", in: John Marincola (ed.), A Companion to Greek and Roman Historiography, Oxford, 461-468.

Housman (1926): Alfred E. Housman (ed.), M. Annaei Lucani Belli Civilis libri decem, Oxford. Houston (1985): George W. Houston, “Tiberius on Capri”, in: G\&R 32, 179-196.

Hübner (1900): Emil Hübner, “Corduba”, in: RE 4, 1221-1224.

Huelsenbeck (2018): Bart Huelsenbeck, Figures in the Shadows. The Speech of Two AugustanAge Declaimers, Arellius Fuscus and Papirius Fabianus, Berlin/Boston.

Hurley (1989): Donna W. Hurley, “Caius Caligula in the Germanicus Tradition”, in: AJPh 110, 316-338.

Hurley (1993): Donna W. Hurley, An Historical and Historiographical Commentary on Suetonius' Life of Caligula, Atlanta.

Hurley (2001): Donna W. Hurley (ed.), Suetonius: Divus Claudius, Cambridge.

Inglebert (1996): Hervé Inglebert, Les Romains chrétiens face à l'histoire de Rome. Histoire, christianisme et romanités en Occident dans l'Antiquité tardive (III'-Ve siècles), Paris.

Isnardi Parente (2000): Margherita Isnardi Parente, "Socrate e Catone in Seneca: il filosofo e il politico", in: Parroni (2000), 215-225.

Jacoby (1949): Felix Jacoby, Atthis: the Local Chronicles of Ancient Athens, Oxford.

Jahn (1852): Otto Jahn (ed.), Iuli Flori Epitomae de Tito Livio bellorum omnium annorum DCC libri II, Leipzig. 
Jal (1963): Paul Jal, La guerre civile à Rome. Étude littéraire et morale, Paris.

Jal (1965): Paul Jal, “Nature et signification politique de l'oeuvre de Florus”, in: REL 43, 358383.

Jal (1967): Paul Jal (ed.), Florus, Oeuvres I-II, Paris.

Janko (2000): Richard Janko (ed.), Philodemus, On Poems, Oxford.

Janko (2008): Richard Janko, “New Fragments of Epicurus, Metrodorus, Demetrius Laco, Philodemus, the Carmen de bello Actiaco and Other Texts in Oxonian Disegni of 1788-1792", in: CErC 38, 5-95.

Kaster (1995): Robert A. Kaster (ed.), C. Suetonius Tranquillus: De grammaticis et rhetoribus, Oxford.

Kaster (2016): Robert A. Kaster (ed.), C. Suetoni Tranquilli De vita Caesarum libros VIII et de grammaticis et rhetoribus librum, Oxford.

Keeline (2018): Thomas J. Keeline, The Reception of Cicero in the Early Roman Empire. The Rhetorical Schoolroom and the Creation of a Cultural Legend, Cambridge.

Keeline/Kirby (2019): Tom Keeline and Tyler Kirby, “Auceps syllabarum: A Digital Analysis of Latin Prose Rhythm” in: JRS 109, 161-204.

Keitel (2014): Elizabeth E. Keitel, “'No Vivid Writing, Please’: Euidentia in the Agricola and the Annals", in: Olivier Devillers (ed.), Les opera minora et le développement de l'historiographie tacitéenne, Bordeaux, 59-70.

Kemezis (2014): Adam Kemezis, Greek Narratives of the Roman Empire under the Severans. Cassius Dio, Philostratus and Herodian, Cambridge.

Kiessling (1872): Adolph Kiessling (ed.), Annaei Senecae Oratorum et rhetorum sententiae divisiones colores, Leipzig.

Kimmerle (2015): Nadja Kimmerle, Lucan und der Prinzipat: Inkonsistenz und unzuverlässiges Erzählen im Bellum Civile, Berlin/Boston.

Kleve (1989): Knut Kleve, “Lucretius in Herculaneum”, in: CErc 19, 5-27.

Kleve (1990): Knut Kleve, “Ennius in Herculaneum”, in: CErc 20, 5-16.

Kleve (1994): Knut Kleve, “An Approach to the Latin Papyri from Herculaneum”, in: Storia, poesia e pensiero nel mondo antico. Studi in onore di M. Gigante, Napoli, 313-320.

Kleve (1996): Knut Kleve, "How to Read an Illegible Papyrus. Towards an Edition of PHerc. 78, Caecilius Statius, Obolostates sive Faenerator”, in: CErc 26, 5-14.

Kleve (2007): Knut Kleve, “Lucretius' Book II in P.Herc. 395”, in: Bernhard Palme (ed.), Akten des 23. internationalen Papyrologenkongresses, Wien, 347-354.

Kleve (2009): Knut Kleve, “Futile Criticism”, in: CErc 39, 281-282.

Klingner (1928): Friedrich Klingner, “Über die Einleitung der Historien Sallusts”, in: Hermes 63, 165-192.

Klingner (1958): Friedrich Klingner, "Tacitus und die Geschichtsschreiber des 1. Jahrhunderts n. Chr.", in: $M H$ 15, 194-206.

Klingner (1965): Friedrich Klingner, Römische Geisteswelt, München.

Klotz (1901): Alfred Klotz, “Das Geschichtswerk des älteren Seneca”, in: RhM 56, 429-442.

Klotz (1909): Alfred Klotz, review of Schendel (1908), in: BPhW 29, 1527-1529.

Klotz (1913): Alfred Klotz, “Die Epitoma des Livius”, in: Hermes 48, 542-557.

Knox (2004): Peter E. Knox, "The Poet and the Second Prince: Ovid in the Age of Tiberius", in: MAAR 49, 1-20.

Koch (2014): Holger Koch, “Neue Beobachtungen zum Geschichtswerk des lulius Florus als eines spätaugusteischen Autors”, in: $A C D$ 50, 101-137.

Koestermann (1963): Erich Koestermann (ed.), Cornelius Tacitus. Annalen I, Heidelberg. 
Koestermann (1965): Erich Koestermann (ed.), Cornelius Tacitus. Annalen II, Heidelberg. Koestermann (1968): Erich Koestermann (ed.), Cornelius Tacitus. Annalen IV, Heidelberg. Kramer (1991): Johannes Kramer, “Die Verwendung des Apex und P.Vindob. L 1 c”, in: ZPE 88, 141-150.

Kraus (2007): Christina S. Kraus, “Historiography and Biography”, in: Stephen Harrison (ed.), A Companion to Latin Literature, Oxford, 241-256.

Krause (1800): Johann Christian Heinrich Krause (ed.), C. Velleii Paterculi quae supersunt ex historiae romanae libris duobus, Leipzig.

Kritz (1848): Friederich Kritz (ed.), M. Vellei Paterculi quae supersunt ex Historiae romanae libris duobus, Leipzig.

Kühnen (1962): Franz Josef Kühnen, Seneca und die römische Geschichte, München (diss.).

La Penna (1967): Antonio La Penna, "Storiografia di senatori e storiografia di letterati”, in: Problemi 57-63, 118-124, 187-195.

La Penna/Funari (2015): Antonio La Penna and Rodolfo Funari (eds), C. Sallusti Crispi Historiae: I: fragmenta 1.1-146, Berlin/Boston.

Lacroix (1951): Jean Lacroix, “Fatum et Fortuna dans l'œuvre de Tacite”, in: REL 29, 247-264.

Lana (1955): Italo Lana, Lucio Anneo Seneca, Bologna.

Lana (1970): Italo Lana, Seneca e la politica, Torino.

Lange/Madsen (2016): Carsten Hjort Lange and Jesper Madsen (eds), Cassius Dio - Greek Intellectual and Roman Politician, Leiden/Boston.

Lange/Vervaet (2019a): Carsten Hjort Lange and Frederik Vervaet (eds), The Historiography of Late Republican Civil War, Leiden/Boston.

Lange/Vervaet (2019b): Carsten Hjort Lange and Frederik Vervaet, "Sulla and the Origins of the Concept of Bellum Civile", in Lange/Vervaet (2019a), 17-28.

Lanza (1977): Diego Lanza, Il tiranno e il suo pubblico, Torino.

Last/Ogilvie (1958): D.M. Last and Robert M. Ogilvie, “Claudius and Livy”, in: Latomus 17, 476487.

Laudizi (2005): Giovanni Laudizi, “Mores ille non verba composuit (Sen. ep. 100, 2)”, in: BStudLat 35, 50-69.

Lausberg (1970): Marion Lausberg, Untersuchungen zu Senecas Fragmenten, Berlin.

Lausberg (1989): Marion Lausberg, "Senecae operum fragmenta. Überblick und Forschungsbericht”, in: ANRW II 36.3, 1879-1961.

Lebek (1976): Wolfgang Dieter Lebek, Lucans Pharsalia. Dichtungsstruktur und Zeitbezug, Göttingen.

Leeman (1963): Anton D. Leeman, Orationis ratio. The Stylistic Theories and Practice of the Roman Orators, Historians and Philosophers, Amsterdam.

Leeman (1974): Anton D. Leeman, Orationis ratio: teoria e pratica stilistica degli oratori, storici e filosofi latini, Bologna.

Leidl (1993): Christoph Leidl, “Appians ‘Annibalike’: Aufbau - Darstellungstendenzen - Quellen”, in: ANRW II 34.1, 428-462.

Lentano (2016): Mario Lentano, "Parlare di Cicerone sotto il governo del suo assassino: la controversia VII, 2 di Seneca e la politica augustea della memoria”, in: Rémy Poignault and Catherine Schneider (eds), Fabrique de la déclamation antique (controverses et suasoires), Lyon, 375-391.

Letta (2019): Cesare Letta, “La carriera politica di Cassio Dione e la genesi della sua Storia Romana", in: SCO 65, 163-180.

Levick (1999): Barbara M. Levick, Tiberius the Politician, London/New York. 
Levick (2015): Barbara M. Levick, Catiline, London/New York.

Lévy (2003): Carlos Lévy, "Sénèque et la circularité du temps", in: Béatrice Bakhouche (ed.), L'ancienneté chez les Anciens II, Montpellier, 491-509.

Lewis (1993): Geoffrey R. Lewis, “Imperial Autobiography, Augustus to Hadrian”, in: ANRW II 34.1, 629-706.

Libourel (1974): Jan Libourel, “An Unusual Annalistic Source used by Dio Cassius”, in: AJPh 95, 383-393.

Lindsay (1890): Wallace M. Lindsay, "The Bodleian Facsimiles of Latin Papyri from Herculaneum", in: $C R$ 4, 441-445.

Lindsay (1999): Hugh M. Lindsay (ed.), Suetonius: Tiberius, North Stratford.

Lintott (1971): Andrew Lintott, "Lucan and the History of the Civil War”, in: CQ 21, 488-505 [repr. in Tesoriero (2010), 239-268].

Lobur (2007): John A. Lobur, “Festinatio (Haste), breuitas (Concision), and the Generation of Imperial Ideology in Velleius Paterculus", in: TAPhA 137, 211-230.

Lombardo (1999): Giovanni Lombardo (ed.), Lo Stile di Demetrio, Palermo.

Lovano (2002): Michael Lovano, The Age of Cinna: Crucible of Late Republican Rome, Stuttgart.

Lucarini (2018): Carlo Martino Lucarini, “Eine Bemerkung zu den neuen Fragmenten des Älteren Seneca (PHerc. Lat. 1067)”, in: ZPE 208, 88-90.

Luce (1964): James Luce, “Appian's Egyptian History”, in: CPh 59, 362-373.

Lühr (1978): Franz-Frieder Lühr, “Weltreiche und Lebensalter. Ein Kapitel Laktanz”, in: AU 21, 19-35.

Mac Culloch (1984): Harold Y. Mac Culloch Jr, Narrative Cause in the Annals of Tacitus, Königstein.

Macrae (2018): Duncan Macrae, “Diligentissumus inuestigator antiquitatis? ‘Antiquarianism' and Historical Evidence between Republican Rome and the Early Modern Republic of Letters", in: Sandberg/Smith (2018), 137-156.

Madsen (2020): Jesper Majbom Madsen, Cassius Dio, London/New York.

Magnino (1993): Domenico Magnino, “Le 'Guerre Civili’ di Appiano”, in: ANRW II 34.1, 523-554.

Mai (1828): Angelo Mai, Classicorum auctorum e Vaticanis codicibus editorum tomus I, com-

plectens Ciceronis De rep. quae supersunt, Gargilii Martialis De arboribus pomiferis, Sallusti Historiarum et Archimedis fragmenta, Roma.

Malcovati (1937): Enrica Malcovati, “Studi su Floro”, in: Athenaeum 15, 69-94, 289-307.

Malcovati (1938): Enrica Malcovati, "Studi su Floro", in: Athenaeum 16, 46-64.

Malcovati (1950): Enrica Malcovati, “Questioni floriane”, in: Athenaeum 28, 276-279.

Malcovati (1972²): Enrica Malcovati (ed.), L. Annaei Flori quae exstant, Roma.

Mallan (2017): Christopher Mallan, “The Parthica of Pseudo-Appian”, in: Historia 66, 362-381.

Malloch (2014): Simon Malloch, “The Fragments of the Roman Historians: Conventions and Opportunities", in: HISTOS 7 [https://research.ncl.ac.uk/histos/documents/WP201407MallochTheFragmentsoftheRomanHistorians.pdf].

Mancini (2018): Alessio Mancini, “Deliberat Nero. Una declamazione 'nascosta' in Suet. Ner. 47.2”, in: Philologus 162, 324-331.

Manuwald (1979): Bernd Manuwald, Cassius Dio und Augustus. Philologische Untersuchungen zu den Büchern 45-56 des dionischen Geschichtswerkes, Wiesbaden.

Marchese (2011): Rosa Rita Marchese, "Et cura vacare et negotio. Cicerone e la storiografia”, in: Hormos 3, 152-162.

Marincola (1997): John Marincola, Authority and Tradition in Ancient Historiography, Cambridge. 
Marincola (1999): John Marincola, “Tacitus’ Prefaces and the Decline of Imperial Historiography", in: Latomus 58, 391-404.

Marincola (2011): John Marincola, “Explanations in Velleius”, in: Cowan (2011), 121-140.

Marouzeau (1940): Jules Marouzeau, review of Bardon (1940a), in: REL 18, 203-205.

Marrou (1964³): Henri-Irénée Marrou, A History of Education in Antiquity, New York.

Marsh (1926): Frank B. Marsh, “Tacitus and the Aristocratic Tradition”, in: CPh 21, 289-310.

Marti (1945): Berthe M. Marti, "The Meaning of the Pharsalia", in: AJPh 66, 352-376.

Martin (2001): Ronald H. Martin (ed.), Tacitus. Annals V and VI, Warminster.

Martin/Woodman (1989): Ronald H. Martin and Anthony J. Woodman (eds), Tacitus Annals Book IV, Cambridge.

Marx (1936): Friedrich A. Marx, “Aufidius Bassus”, in: Klio 29, 94-101.

Marx (1937-1938): Friedrich A. Marx, "Tacitus und die Literatur der exitus illustrium virorum", in: Philologus 92, 83-103.

Mastandrea (2002): Paolo Mastandrea, “'Navigare necesse': esplorando il frammento di Pedone Albinovano", in: Lexis 20, 107-121.

Mastandrea (2017): Paolo Mastandrea, “Caesareana tempora e 'Historia Augusta' (Vita Aureliani 6, 4). Su certe periodizzazioni della storia romana proposte dagli scrittori tardoantichi”, in: Lucio Cristante and Vanni Veronesi (eds), Il calamo della memoria VII. Raccolta delle relazioni discusse nell'incontro internazionale di Trieste, Biblioteca statale, 29-30 settembre 2016, Trieste, 205-227.

Maurenbrecher (1891-1893): Bertold Maurenbrecher (ed.), C. Sallusti Crispi Historiarum reliquiae, Leipzig.

Mayer (2005): Roland G. Mayer, “The Impracticability of Latin 'Kunstprosa”, in: Reinhardt et all. (2005), 195-210.

Mazzarino (1966): Santo Mazzarino, Il pensiero storico classico, Bari.

Mazzoli (1967): Giancarlo Mazzoli, “Genesi e valore del motivo escatologico in Seneca. Contributo alla questione posidoniana”, in: RIL 101, 203-262.

Mazzoli (2006): Giancarlo Mazzoli, “La guerra civile nelle declamazioni di Seneca il Retore”, in: Ciceroniana 12, 45-57.

Mazzoli (2012): Giancarlo Mazzoli, “Civis, civilis, civitas. Un campo semantico nella riflessione socio-politica di Seneca”, in: Mario Citroni (ed.), Letteratura e civitas. Transizioni dalla Repubblica all'Impero, in ricordo di Emanuele Narducci, Pisa, 327-340.

Mazzoli (2016): Giancarlo Mazzoli, Il chaos e le sue architetture. Trenta studi su Seneca tragico, Palermo.

McGing (2018): Brian McGing, “Appian, the Third Punic War”, in: Nikos Miltsios and Melina Tamiolaki (eds), Polybius and his Legacy, Berlin/Boston, 341-356.

Meyer (1894): Eduard Meyer, Untersuchungen zur Geschichte der Gracchen, Halle (repr. in: Kleine Schriften, Halle 1924, 363-421).

Michel (1962): Alain Michel, Le Dialogue des Orateurs de Tacite et la philosophie de Cicéron, Paris.

Migliario (1989): Elvira Migliario, “Luoghi retorici e realtà sociale nell’opera di Seneca il Vecchio”, in: Athenaeum 67, 525-549.

Migliario (2007): Elvira Migliario, Retorica e Storia. Una lettura delle Suasoriae di Seneca Padre, Bari.

Milkau (1888): Fritz Milkau, De Vellei Paterculi genere dicendi, Königsburg (diss.).

Millar (1964): Fergus Millar, A Study of Cassius Dio, Oxford.

Miltner (1952): Franz Miltner, “Der Tacitusbericht über Idistaviso”, in: RhM 95, 343-346. 
Mineo (2006): Bernard Mineo, Tite-Live et l'histoire de Rome, Paris.

Momigliano (1950): Arnaldo Momigliano, “Ancient History and the Antiquarian”, in: JWCI 13, 285-315.

Momigliano (1958): Arnaldo Momigliano, "Some observations on the 'Origo Gentis Romanae", in: JRS 48, 56-73.

Momigliano (1961a): Arnaldo Momigliano, review of Syme (1958a), in: Gnomon 33, 55-58.

Momigliano (1961b): Arnaldo Momigliano, Claudius. The Emperor and his Achievement, Cambridge.

Moravski (1876): Kalikst von Morawsky, “Beiträge zur Charakteristik der Sprache des Velleius”, in: Philologus 35, 715-717.

Moravski (1882): Kalikst von Morawsky, “Zu lateinischen Schriftstellern”, in: WS 4, 166-168.

Morello (2006): Ruth Morello, “A Correspondence Course in Tyranny: The Cruentae Litterae of Tiberius”, in: Arethusa 39, 331-354.

Müller (1887): Hermann J. Müller (ed.), L. Annaei Senecae Oratorum et rhetorum sententiae divisiones colores, Vindobonae.

Müller (1954): Karl Müller (ed.), Q. Curtius Rufus. Geschichte Alexanders des Grossen, München.

Muntz (2017): Charles Muntz, Diodorus Siculus and the World of the Late Roman Republic, New York.

Murray (2010): Oswyn Murray, “Niebuhr in Britain”, in: Chryssanthi Avlami and Jaime Alvar (eds), Historiographie de l'antiquité et transferts culturels: les histoires anciennes dans l'Europe des XVIIIe et XIXe siècles, Amsterdam/New York, 239-254.

Naas (2002): Valérie Naas, Le projet encyclopédique de Pline l'Ancien, Roma.

Narducci (2002): Emanuele Narducci, Lucano: un'epica contro l'impero: interpretazione della Pharsalia, Roma/Bari.

Neuhausen (1992): Karl August Neuhausen, “Florus’ Einteilung der römischen Geschichte und seiner historischen Schrift in Lebensalter. Echte und interpolierte Altersstufen im überlieferten Prooem als Schüssel zu einer neuen Datierung der 'Epitome’”, in: Henri Dubois and Michel Zink (eds), Les âges de la vie au Moyen Âge, Paris, 217-252.

Neuhausen (1994): Karl August Neuhausen, “Der überhörte 'Schwanengesang' der augusteischen Literatur: eine Rekonstruktion der Originalfassung (um $15 \mathrm{n}$. Chr.) des bisher dem 2. Jahrhundert zugeordneten Geschichtswerkes des Florus", in: ACD 30, 149-207.

Niebuhr (1820): Barthold G. Niebuhr (ed.), M. Tullii Ciceronis orationum pro M. Fonteio et pro C. Rabirio fragmenta, T. Livii lib. XCl. fragmentum plenius et emendatius, L. Senecae fragmenta ex membranis bibliothecae Vaticanae, Roma.

Niebuhr (1828/1870): Barthold G. Niebuhr, Lectures on the History of Rome, London.

Nissen (1863): Heinrich Nissen, Kritische Untersuchungen über die Quellen der vierten und fünften Dekade des Livius, Berlin.

Nodar/Torallas (2019): Alberto Nodar and Sofia Torallas (eds), Proceedings of the 28th International Congress of Papyrology (Barcelona, August 2016), Barcelona.

Noè (1984): Eralda Noè, Storiografia imperiale pretacitiana. Linee di svolgimento, Firenze.

Norden (1915): Eduard Norden, Die antike Kunstprosa vom vi. Jahrhundert v. Chr. bis in die Zeit der Renaissance, Leipzig.

Nordh (1952): Arvast Nordh, “Virtus and Fortuna”, in: Eranos 50, 111-128.

O’Gorman (1995): Ellen O’Gorman, “On not Writing about Augustus: Tacitus' “Annals” Book I”, in: $M D$ 35, 91-114.

Oakley (1997-2005): Stephen P. Oakley, A Commentary on Livy. Books vi-x, Oxford. 
Oakley (2016): Stephen P. Oakley, “The Proto-History of the Text of Livy”, in: Javier Velaza (ed.), From the Protohistory to the History of the Text, Frankfurt, 165-186.

Olbrycht (2012): Marek Jan Olbrycht, "The Political-Military Strategy of Artabanos/Ardawān II in AD 34-37", in: Anabasis: Studia classica et orientalia 3, 215-237.

Olbrycht (2016): Marek Jan Olbrycht, "Germanicus, Artabanos II of Parthia, and Zeno Artaxias in Armenia”, in: Klio 98, 605-633.

Oliver (1951): Revilo P. Oliver, "The First Medicean MS of Tacitus and the Titulature of Ancient Books", in: TAPhA 82, 232-261.

Olivier (1980): Revilo P. Oliver, “Thrasyllus in Tacitus (Ann. 6. 21)”, in: ICS 5, 130-148.

Oniga (2003): Renato Oniga (ed.), Tacito, Opera omnia II, Torino.

Osgood (2015): Josiah Osgood, “Breviarium totius imperii: The Background of Appian's Roman History”, in: Welch (2015), 23-44.

Osgood/Baron (2019): Josiah Osgood and Christopher Baron (eds), Cassius Dio and the Late Roman Republic, Leiden/Boston.

Pani (1991): Mario Pani, “Lotte per il potere e vicende dinastiche. Il principato fra Tiberio e Nerone", in: Andrea Schiavone and Arnaldo Momigliano (eds), Storia di Roma II 2, Torino, 221-252.

Paratore (1949): Ettore Paratore, “Tacito”, in: Maia 2, 93-120.

Paratore (1951): Ettore Paratore, Tacito, Varese.

Parks (1945): Edilbert Patrick Parks, The Roman Rhetorical Schools as a Preparation for the Courts under the Early Empire, Baltimore.

Parroni (2000): Piergiorgio Parroni (ed.), Seneca e il suo tempo. Atti del Convegno internazionale di Roma-Cassino, 11-14 novembre 1998, Roma.

Paschoud (2002): François Paschoud (ed.), Histoire Auguste, V, 2. Vies de Probus, Firmus, Saturnin, Proculus et Bonose, Carus, Numérien et Carin, Paris.

Pecere (2010): Oronzo Pecere, Roma antica e il testo: scritture d'autore e composizione letteraria, Roma/Bari.

Pelling (1997): Christopher Pelling, “Biographical History? Cassius Dio on the Early Principate”, in: Michael Edwards and Simon Swain (eds), Portraits. Biographical Representation in the Greek and Latin Literature of the Roman Empire, Oxford, 117-144.

Pelling (2002): Christopher Pelling, Plutarch and History: Eighteen Studies, London.

Pelling (2011a): Christopher Pelling (ed.), Plutarch: Caesar, Oxford.

Pelling (2011b): Christopher Pelling, "Velleius and Biography: the Case of Julius Caesar”, in: Cowan (2011), 121-140.

Perrelli (2017): Raffaele Perrelli, “L’Adriano di Floro”, in: Koinonia 41, 131-146.

Peter (1906): Hermann Peter (ed.), Historicorum Romanorum reliquiae II, Leipzig.

Peter (1914²): Hermann Peter (ed.), Historicorum Romanorum reliquiae I, Leipzig.

Petronio Nicolaj (1973): Giovanna Petronio Nicolaj, "Osservazioni sul canone della capitale libraria romana fra I e III secolo”, in: Miscellanea in memoria di G. Cencetti, Torino, 3-27.

Petrovićová (2015): Katarina Petrovićová, “Augustusbild im rhetorischen Werk von Seneca Rhetor", in: AAntHung 55, 489-502.

Pettinger (2012): Andrew Pettinger, The Republic in Danger. Drusus Libo and the Succession of Tiberius, Oxford.

Pfordt (1998): Matthias Pfordt, Studien zur Darstellung der Außenpolitik in den Annalen des Tacitus, Bern.

Piano (2016): Valeria Piano, “Sull'autore del PHerc. 1067: una nuova lettura della subscriptio", in: AnPap 28, 273-283. 
Piano (2017a): Valeria Piano, “Il PHerc. 1067 latino: il rotolo, il testo, l’autore”, in: CErc 47, $163-250$.

Piano (2017b): Valeria Piano, “Dell'importanza di un progetto rimasto incompiuto: Robert Marichal e i papiri latini della biblioteca di Ercolano", in: Scappaticcio (2017), 27-47.

Piano (2018): Valeria Piano, “P.Herc. 1067: alcune considerazioni bibliologiche”, in: Anna Di Natale and Corrado Basile (eds), Atti del XVI Convegno di Egittologia e Papirologia (Quaderni del Museo XV), Siracuse 89-109.

Piano (2019): Valeria Piano, “P.Herc. 1067 Reconsidered: Latest Results, New Perspectives”, in: Nodar/Torallas (2019), 231-240.

Pichon (1912): René Pichon, Les sources de Lucain, Paris.

Piganiol (1932): André Piganiol, review of Nicolae Barbu, Les sources et l'originalité d'Appien dans le deuxième livre des Guerres civiles, in: REG 48, 615-616.

Piganiol (1962): André Piganiol, Histoire de Rome 5 , Paris.

Pistellato (2012): Antonio Pistellato, "Historiographie des guerres civiles et guerre civile des historiographies: Publius Vatinius”, in: Sylvain Destephen and Robinson Baudry (eds), La société romaine et ses élites, mélanges offerts à Elizabeth Deniaux, Paris, 43-51.

Pistellato (2015a): Antonio Pistellato, Stirpem nobilitavit honor: la memoria dei Senzi Saturnini tra retorica e storiografia, Amsterdam.

Pistellato (2015b): Antonio Pistellato, “Imago nominis: lo strano caso di Publio Vatinio e del suo doppio", in: Tomaso Maria Lucchelli and Francesca Rohr Vio (eds), Viri militares. Rappresentazione e propaganda tra Repubblica e Principato, Trieste, 201-230.

Pistellato (2016): Antonio Pistellato, review of La Penna/Funari (2015), in: Lexis 34, 467-472.

Pittà (2015): Antonino Pittà (ed.), M. Terenzio Varrone, De vita populi Romani, Pisa.

Platon (2016): Marie Platon, "Sénat et pouvoir impérial dans les livres 57 et 58 de l'Histoire romaine de Cassius Dion”, in: Fromentin et all. (2016), 653-675.

Pohlenz (1927): Max Pohlenz, “Causae civilium armorum”, in: Epitymbion H. Swoboda dargebracht, Reichenberg, 201-210 [repr. in Pohlenz (1965), 139-148].

Pohlenz (1965): Max Pohlenz, Kleine Schriften, Hildesheim.

Potter (1999): David S. Potter, "Political Theory in the Senatus Consultum Pisonianum", in: Damon/Takács (1999), 65-88.

Power (2014a): Tristan Power, “Introduction: The Originality of Suetonius”, in: Power/Gibson (2014), 1-18.

Power (2014b): Tristan Power, “The Endings of Suetonius' Caesars”, in: Power/Gibson (2014), 58-77.

Power/Gibson (2014): Tristan Power and Roy K. Gibson (eds), Suetonius the Biographer. Studies in Roman Lives, Oxford.

Preisendanz (1908): Karl Preisendanz, “De L. Annaei Senecae rhetoris apud philosophum filium auctoritate”, in: Philologus 67, 68-112.

Questa (1957): Cesare Questa, “Il viaggio di Germanico in Oriente e Tacito”, in: Maia 9, 291-321.

Questa (1963²): Cesare Questa, Studi sulle fonti degli Annales di Tacito, Roma.

Raaflaub/Samons (1990): Kurt Raaflaub and Loren J. Samons, "Opposition to Augustus", in: Kurt Raaflaub and Mark Toher (eds), Between Republic and Empire, Berkeley/Los Angeles/ London, 417-454.

Radiciotti (1998): Paolo Radiciotti, “Osservazioni paleografiche sui papiri latini di Ercolano”, in: $S \& C 22,353-370$.

Radiciotti (2000): Paolo Radiciotti, “Della genuinità e delle opere tradite da alcuni antichi papiri latini”, in: S\&C 24, 359-373. 
Radiciotti (2008): Paolo Radiciotti, “Per Knut Kleve. Riflessioni sulla paleografia”, in: PapLup $17,51-60$.

Radiciotti (2009): Paolo Radiciotti, “Ercolano: papiri latini in una biblioteca greca”, in: SEP 6, 103-114.

Radicke (2004): Jan Radicke, Lucans poetische Technik. Studien zum historischen Epos, Leiden/Boston.

Rambaud (1948): Michel Rambaud, "Salluste et Trogue-Pompée”, in: REL 26, 171-189.

Ramondetti (2002): Paola Ramondetti, "Svetonio e la morte di Tiberio", in: Quaderni del Dipartimento di filologia, linguistica e tradizione classica "Augusto Rostagni" 1, 213-223.

Ramsey (2005): John T. Ramsey, “Mark Antony's Judiciary Reform and its Revival under the Triumvirs”, in: JRS 95, 20-37.

Rathmann (2016): Michael Rathmann, Diodor und seine "Bibliotheke": Weltgeschichte aus der Provinz, Berlin/Boston.

Rawson (1985): Elizabeth Rawson, Intellectual Life in the Late Roman Republic, London.

Reifferscheid (1860): Augustus Reifferscheid (ed.), C. Suetoni Tranquilli praeter Caesarum libros reliquiae, Leipzig.

Reinard (2015): Patrick Reinard, “Divisa namque et discors aula erat. Die Germanicus-Münzen des Tiberius, Caligula und Claudius: Beobachtungen zur Julisch-Claudischen Dynastie”, in: MBAHWS 33, 157-212.

Reinhardt et all. (2005): Tobias Reinhardt, Michael Lapidge, and James N. Adams (eds), Aspects of the language of Latin prose, Oxford.

Rich (1989): John W. Rich, “Dio on Augustus”, in: Averil Cameron (ed.), History as Text. The Writing of Ancient History, Chapel Hill, 87-110.

Rich (1990): John W. Rich, Cassius Dio, The Augustan Settlement (Roman History 53-55.9), Warminster.

Rich (2011): John W. Rich, "Structuring Roman History: The Consular Year and the Roman Historical Tradition", in: Histos 5, 1-41.

Rich (2015): John W. Rich, “Appian, Polybius and Rome's War with Antiochus the Great: A Study in Appian's Sources and Methods", in: Welch (2015), 65-123.

Rich (2016): John W. Rich, “Annalistic Organization and Book Division in Dio's Books 1-35”, in: Fromentin et all. (2016), 271-286.

Rich (2018): John W. Rich, “Fabius Pictor, Ennius and the Origins of Roman Annalistic Historiography”, in: Sandberg/Smith (2018), 17-65.

Rich (forthcoming): John W. Rich, “Appian, Cassius Dio and the Roman Republic”, in: Valentina Arena and Jonathan Prag (eds), A Companion to the Political Culture of the Roman Republic, Chichester/Malden.

Richter (1961): Will Richter, “Römische Zeitgeschichte und innere Emigration”, in: Gymnasium 68, 286-315.

Rietra (1928): Joannes R. Rietra (ed.), C. Suetoni Tranquilli vita Tiberi, c. 24-c. 40, Paris.

Rimell (2015): Victoria Rimell, "Seneca and Neronian Rome: in the Mirror of Time", in: Shadi Bartsch and Alessandro Schiesaro (eds), The Cambridge Companion to Seneca, Cambridge, 122-134.

Riposati (1939): Benedetto Riposati (ed.), M. Terenti Varronis De vita populi romani: fonti, esegesi, edizione critica dei frammenti, Milano.

Rocca (1989): Rosanna Rocca, Epici minori d'età augustea, Genova.

Roche (2009): Paul Roche (ed.), Lucan, De bello civili, Book I, Oxford. 
Rohr Vio (2000): Francesca Rohr Vio, Le voci del dissenso: Ottaviano Augusto e i suoi oppositori, Padova.

Rolland (1906): Edouard Rolland, De l'influence de Sénèque le Père et des rhéteurs sur Sénèque le Philosophe, Gand.

Roller (1997): Matthew B. Roller, “Color-Blindness: Cicero’s Death, Declamation, and the Production of History", in: CPh 92, 109-130.

Ronconi (1968): Alessandro Ronconi, Da Lucrezio a Tacito, Firenze.

Rossbach (1888): Otto Rossbach, De Senecae philosophi librorum recensione et emendatione, Vratislaviae.

Rossbach (1894): Otto Rossbach, “Annaeus”, in: RE 1, 2237-2240.

Rossbach (1896): Otto Rossbach (ed.), L. Annaei Flori Epitomae libri Il et P. Annii Flori fragmentum De Vergilio oratore an poeta, Leipzig.

Rossbach (1903): Otto Rossbach, supplement to Rossbach (1894), in: RE Suppl. 1, 84-85.

Rossbach (1909): Otto Rossbach, "Florus", in: RE 6, 2761-2770.

Rostagni (1964): Augusto Rostagni, Storia della letteratura latina, Torino.

Ruch (1972): Michel Ruch, "Le thème de la croissance organique dans la pensée historique des Romains de Caton à Florus”, in: ANRW I 2, 827-841.

Sacks (1990): Kenneth Sacks, Diodorus Siculus and the First Century, Princeton.

Sage (1990): Michael M. Sage, “Tacitus' Historical Works: a Survey and Appraisal”, in: ANRW II 33.2, 853-1030, 1629-1647.

Sallmann (1984): Klaus Sallmann, “Der Traum des Historikers: Zu den ‘Bella Germaniae’ des Plinius und zur julisch-claudischen Geschichtsschreibung”, in: ANRW II 32.1, 578-601.

Salomone Gaggero (1981): Eleonora Salomone Gaggero (ed.), Floro, Epitome di Storia Romana, Milano.

Salvo (2010): Davide Salvo, “Germanico e la rivolta delle legioni del Reno", in: Hormos 2, 138156.

Sandberg/Smith (2018): Kaj Sandberg and Christopher Smith (eds), Omnium Annalium Monumenta: Historical Writing and Historical Evidence in Republican Rome, Leiden/Boston.

Sanford (2016): Eva Matthews Sanford, “Lucan and Civil War”, in: CPh 28, 121-127.

Santorelli (2016): Biagio Santorelli, “Aktualisierung”, in: Håkanson (2016), 143-148.

Santos-Yanguas (1981-1982): Narciso Santos-Yanguas, “La concepción de la historia de Roma como sucesión de edades en los historiadores latinos", in: CFC 17, 173-184.

Sauppe (1837): Hermann Sauppe, “M. Velleius Paterculus”, in: Schweizerisches Museum für Historische Wissenschaft 1, 133-180.

Scappaticcio (2008): Maria Chiara Scappaticcio, “Il PHerc. 817: spunti paleografici”, in: CErc 38, 229-246.

Scappaticcio (2010): Maria Chiara Scappaticcio, “Il PHerc. 817: echi virgiliani e 'pseudoaugusteismo'”, in: CErc 40, 99-136.

Scappaticcio (2012): Maria Chiara Scappaticcio, Accentus, distinctio, apex. L'accentazione grafica tra grammatici latini e papiri virgiliani, Turnhout.

Scappaticcio (2017): Maria Chiara Scappaticcio (ed.), Per i testi latini su papiro: prime riflessioni sul fondo inedito di Robert Marichal (Bibliotheca-GIF 17), Turnhout.

Scappaticcio (2018): Maria Chiara Scappaticcio, “Lucio Anneo Seneca e la storiografia sommersa: per l'esegesi di un nuovo testimone di antica tradizione diretta”, in: Latomus 77, 1053-1089. 
Scappaticcio (2019): Maria Chiara Scappaticcio, “Papyri and LAtin Texts: INsights and Updated Methodologies. Towards a Philological, Literary, and Historical Approach to Latin Papyri (PLATINUM Project - ERC-StG 2014 no. 636983)", in: Noda /Torallas (2019), 619-627.

Schanz/Hosius (1935): Martin Schanz and Carl Hosius, Geschichte der römischen Literatur bis zum Gesetzgebungswerk des Kaisers Justinian II, München.

Schendel (1908): Heinrich Schendel, Quibus auctoribus Romanis L. Annaeus Seneca in rebus patriis usus sit, Gryphiae (diss.).

Schiesaro (2000): Alessandro Schiesaro, “Estetica della tirannia”, in: Parroni (2000), 135-159.

Scholz (1994): Udo Scholz, “Annales und Historia(e)", in: Hermes 122, 64-79.

Schulten (1905): Adolf Schulten, Numantia. Eine topographisch-historische Untersuchung, Berlin.

Schwartz (1896): Eduard Schwartz, “Appianus (2)”, in: RE 2, 216-237.

Schwartz (1899): Eduard Schwartz, "Cassius Dio", in: RE 3, 1684-1722.

Scott (1932): Kenneth Scott, “Tiberius' Refusal of the Title 'Augustus', in: CPh 27, 43-50.

Seager $\left(2005^{2}\right)$ : Robin Seager, Tiberius, Malden.

Seewald (1998): Martin Seewald, “Ein Anonymus der frühen Kaiserzeit. Zu Lucan. 9,167-185 und Tac. ann. 3,1-2", in: GFA 1, 58-80.

Sehlmeyer (2007): Markus Sehlmeyer, “Die Anfänge der antiquarische Literatur in Rom”, in: Ulrich Eigler, Ulrich Gotter, Nino Luraghi, and Uwe Walter (eds), Formen römischer Geschichtsschreibung von den Anfängen bis Livius, Darmstadt, 157-171.

Seider (1978): Richard Seider, Paläographie der lateinischen Papyri, Il, Literarische Papyri, 1, Texte klassicher Autoren, Stuttgart.

Sellge (1882): Henry Julius Sellge, Symbola ad historiam librorum Sallustianorum condendam datur. 1. De studiis in Sallustio Crispo Pompeio Trogo et lustino epitomatore collocatis, Sagani (diss.).

Setaioli (2000): Aldo Setaioli, Facundus Seneca. Aspetti della lingua e dell'ideologia senecana, Bologna.

Shackleton Bailey (1968): David R. Shackleton Bailey (ed.), Cicero's Letters to Atticus, Volume IV (Books VII.10 - X), Cambridge.

Sihler (1894): Ernest G. Sihler, “On Velleius Paterculus”, in: TAPhA 25, xlv-xlix.

Sinclair (1995): Patrick Sinclair, Tacitus the Sententious Historian. A Sociology of Rhetoric in Annales 1-6, University Park.

Skydsgaard (1968): Jens Erik Skydsgaard, Varro the Scholar: Studies in the First Book of Varro's De Re Rustica, Copenhagen.

Slater (2014): Niall W. Slater, "Speaking Verse to Power: Circulation of Oral and Written Critique in the Lives of the Caesars", in: Ruth Scodel (ed.), Between Orality and Literacy: Communication and Adaptation in Antiquity, Leiden, 289-308.

Smith (2018): Christopher Smith, “On the Edges of History”, in: Sandberg/Smith (2018), 115136.

Smith (forthcoming): Christopher Smith, “The Lives of Augustus”, in: Yves Lehmann (ed.), Mélanges Martine Chassignet, Turnhout.

Sochatoff (1939): Fred A. Sochatoff, "Basic Rhetorical Theories of the Elder Seneca”, in: CJ 34 , 345-354.

Sordi (1999): Marta Sordi, “Introduzione”, in: Marta Sordi, Alessandro Stroppa and Alessandro Galimberti (eds), Cassio Dione. Storia Romana (libri LVII-LXIII), Milano, 5-24.

Spengel (1860): Leonhard Spengel, “Ueber die Geschichtsbücher des Florus”, in: ABAW 9, 319-350. 
Stadler (2015): Thiago D. Stadler, “Do emprego da palavra 'história’ no Prefácio Epistolar da História Natural de Plínio, o Velho (séc. I d.C.)”, in: Revista Diálogos Mediterrânicos 8, 242-258.

Starr (1981): Raymond J. Starr, “The Scope and Genre of Velleius' History”, in: CQ 31, 162-174.

Starr (1987): Raymond J. Starr, "The Circulation of Literary Texts in the Roman World", in: CQ 37, 213-223.

Staveley (1953): Stuart E. Staveley, “/udex selectus”, in: RhM 96, 201-213.

Stevenson (2004): Andrew Stevenson, "Gellius and the Antiquarian Tradition", in: Leofranc Holford-Strevens and Amiel Vardi (eds), The Worlds of Aulus Gellius, Oxford, 118-155.

Stewart (1953): Zeph Stewart, “Sejanus, Gaetulicus, and Seneca”, in: AJPh 74, 70-85.

Strunk (2010): Thomas E. Strunk, "Saving the Life of a Foolish Poet: Tacitus on Marcus Lepidus, Thrasea Paetus, and Political Action under the Principate”, in: SyllClass 21, 119-139.

Studemund (1888): Wilhelm Studemund (ed.), “L. Annaei Senecae librorum quomodo amicitia continenda sit et de vita patris quae supersunt”, in: Rossbach (1888), i-xxxii.

Suerbaum (2019): Werner Suerbaum "Die neuentdeckten Historiae ab initio bellorum civilium des Seneca pater mit einer Anrede an Augustus und Velleius Paterculus Überlegungen zur Interpretation des PHerc. 1067", in: ZPE 211, 44-63.

Sumner (1970): Graham Sumner, “The Truth about Velleius Paterculus: Prolegomena”, in: HSCPh 74, 257-297.

Sussman (1969): Lewis A. Sussman, The Elder Seneca as a Critic of Rhetoric, Chapel Hill (diss.).

Sussman (1971): Lewis A. Sussman, "The Artistic Unity of the Elder Seneca's First Preface and the Controversiae as a Whole", in: AJPh 92, 285-291.

Sussman (1972): Lewis A. Sussman, “The Elder Seneca's Discussion of the Decline of Roman Eloquence”, in: CSCA 5, 195-210.

Sussman (1977): Lewis A. Sussman, “Arellius Fuscus and the Unity of the Elder Seneca's Suasoriae", in: RhM 120, 303-323.

Sussman (1978): Lewis A. Sussman, The Elder Seneca, Leiden.

Swan (1987): Peter M. Swan, “Cassius Dio on Augustus: a Poverty of Annalistic Sources?”, in: Phoenix 41, 272-291.

Swan (1997): Peter M. Swan, “How Cassius Dio Composed his Augustan Books: Four Studies”, in: ANRW II 34.3, 2524-2557.

Swan (2004): Peter M. Swan, The Augustan Succession. A Historical Commentary on Cassius Dio's Roman History Books 55-56 (9 BC-AD 14), New York.

Syme (1933): Ronald Syme, “M. Vinicius (cos. 19 BC)”, in: CQ 27, 142-148.

Syme (1939): Ronald Syme, The Roman Revolution, Oxford.

Syme (1957): Ronald Syme, “How Tacitus Came to History”, in: G\&R 24, 160-167.

Syme (1958a): Ronald Syme, Tacitus, Oxford.

Syme (1958b): Ronald Syme, “The Senator as Historian”, in: Histoire et historiens dans l'Antiquité, Genève, 187-201.

Syme (1959): Ronald Syme, “Livy and Augustus”, in: HSCPh 64, 27-87.

Syme (1964): Ronald Syme, “The Historian Servilius Nonianus”, in: Hermes 92, 408-414.

Syme (1968): Ronald Syme, Ammianus and the Historia Augusta, Oxford.

Syme (1970): Ronald Syme, Ten Studies in Tacitus, Oxford.

Syme (1971): Ronald Syme, Emperors and Biography: Studies in the Historia Augusta, Oxford.

Syme (1974): Ronald Syme, “History or Biography: The Case of Tiberius Caesar”, in: Historia 23, 481-496. 
Syme (1977): Ronald Syme, “How Tacitus wrote Annals I-III”, in: Historiographia Antiqua: commentationes Lovanienses in honorem W. Peremans septuagenarii editae, Leuven, 231263.

Syme (1980): Ronald Syme, “Biographers of the Caesars”, in: $M H$ 37, 104-128.

Syme (1982): Ronald Syme, “Tacitus: Some Sources of His Information”, in: JRS 72, 68-82.

Syme (1986): Ronald Syme, The Augustan Aristocracy, Oxford.

Syme (1987): Ronald Syme, “M. Bibulus and Four Sons”, in: HSCPh 91, 185-198.

Tabacco (1985): Raffaella Tabacco, "Il tiranno nelle declamazioni di scuola in lingua latina" in: MAT II 9, 1-141.

Talbert (1984): Richard J. A. Talbert, The Senate of Imperial Rome, Princeton.

Talbert (1999): Richard J. A. Talbert, "Tacitus and the Senatus Consultum de Cn. Pisone Patre", in: Damon/Takács (1999), 89-97.

Tamás (2014): Ábel Tamás, “Geheimnis und Gerücht. Die Geschichte des falschen Agrippa bei Tacitus (Ann. 2.39-40)”, in: Zoltán Kulcsár-Szabó and Csongor Lörincz (eds), Signaturen des Geschehens. Ereignisse zwischen Öffentlichkeit und Latenz, Bielefeld, 287-308.

Tandoi (1964, 1967): Vincenzo Tandoi, “Albinovano Pedone e la retorica giulio-claudia delle conquiste”, in: SIFC 36, 120-168; 39, 5-66 (repr. in Vincenzo Tandoi, Scritti di filologia e di storia della cultura classica I, Pisa, 1992, 509-585).

ten Berge (2019): Bram ten Berge, “Epitomizing Discord: Florus on the Late Republican Civil Wars", in: Lange/Vervaet (2019a), 411-438.

Tesoriero (2010): Charles Tesoriero (ed.), Lucan, Oxford.

Teuffel (1902'): Wilhelm S. Teuffel, Geschichte der römischen Literatur II, Leipzig.

Tibiletti (1959): Carlo Tibiletti, “Il proemio di Floro, Seneca il Retore e Tertulliano", in: Convivium 27, 339-342.

Toher (1990): Mark Toher, “Augustus and the Evolution of Roman Historiography”, in: Kurt Raaflaub and Mark Toher, Between Republic and Empire, Berkeley/Los Angeles/London, 139-154.

Toohey (2015): Kathleen Toohey, “The Early ‘mperial Annalists”, in: Nova, 16-18.

Torre (2017): Chiara Torre, “In primum Tiberii Caesaris principatum iuventae tempus inciderat: note senecane sulla cultura filosofica di età tiberiana”, in: Vichiana 54, 93-107.

Torri (2002-2003): Marcos Torri, “La réception de la propagande d’Auguste chez Sénèque le Rhéteur”, in: Classica 15-16, 117-130.

Touahri (2010): Ouardia Touahri, "Le phénomène de la guerre civile d'après Sénèque le Rhéteur”, in: Pierre-Louis Malosse, Marie-Pierre Noël and Bernard Schouler (eds), Clio sous le regard d'Hermès. L'utilisation de l'histoire dans la rhétorique ancienne de l'époque hellénistique à l'Antiquité tardive, Alessandria, 55-64.

Townend (1960): Gavin B. Townend, “The Sources of Greek in Suetonius”, in: Hermes 88, 98120.

Townend (1961a): Gavin B. Townend, “The Hippo Inscription and the Career of Suetonius", in: Historia 10, 99-109.

Townend (1961b): Gavin B. Townend, “Traces in Dio Cassius of Cluvius, Aufidius and Pliny”, in: Hermes 89, 227-248.

Townend (1962): Gavin B. Townend, “Claudius and the Digressions in Tacitus”, in: RhM 105, 358-368.

Tränkle (1969): Hermann Tränkle, “Augustus bei Tacitus, Cassius Dio und dem älteren Plinius”, in: WS 82, 108-130.

Tränkle (1980): Hermann Tränkle, “Zu Cremutius Cordus, fr. 4”, in: MH 37, 231-241. 
Trillitzsch (1971): Winfried Trillitzsch, Seneca im literarischen Urteil der Antike, Amsterdam.

Trinacty (2009): Christopher Trinacty, "Like Father, Like Son? Selected Examples of Intertextuality in Seneca the Younger and Seneca the Elder", in: Phoenix 63, 260-277.

Troiani (2004): Lucio Troiani, “Un console repubblicano sotto la dinastia Giulio-Claudia”, in: REL 138, 69-78.

Turpin (2008): William Turpin, “Tacitus, Stoic exempla, and the praecipuum munus annalium", in: ClAnt 27, 359-404.

Ullman (1943): Berthold L. Ullman, "Sine Ira et Studio", in: CJ 38, 420-421.

Unger (1884): Georg Friedrich Unger, “Die vier Zeitalter des Florus”, in Philologus 43, 429-443. Urban (1979): Ralf Urban, "Tacitus und die Res gestae divi Augusti”, in: Gymnasium 86, 59-74. Urso (2016): Gianpaolo Urso, “Cassius Dion témoin de traditions disparues: les premiers siècles de la République”, in: Fromentin et all. (2016), 143-158.

Urso (2018): Gianpaolo Urso, "Cassio Dione e le fonti preliviane: una versione alternativa dei primi secoli di Roma”, in: Burden-Strevens/Lindholmer (2018), 53-75.

van der Blom (2019): Henriette van der Blom, "Bellum Civile in Cicero: Terminology and Selffashioning”, in: Lange/Vervaet (2019a), 111-136.

Vattuone (1983-1984): Riccardo Vattuone, “Tre note a Suetonio, Vita Tiberii 52", in: RSA 13-14, 213-235.

Velaza (1993): Javier Velaza, “Tácito y Augusto (Ann. I 9-10)”, in: Emerita 61, 335-356.

Verbrugghe (1989): Gerard P. Verbrugghe, "On the Meaning of Annales, on the Meaning of Annalist”, in: Philologus 133, 192-230.

Viansino (1974): Giovanni Viansino, Studi sul Bellum civile di Lucano, Salerno.

Vielberg (1996): Meinof Vielberg, “Ingenium und Mores: Beobachtungen zur historischen Begriffsbildung an Tac. Ann. 6, 51, 3", in: Mnemosyne 49, 452-456.

Vittingoff (1954): Friedrich Vittingoff, "Zur Rede des Kaisers Claudius über die Aufnahme von 'Galliern' in den römischen Senat”, in: Hermes 82, 348-371.

Vogt (1975): William C. Vogt, Suetonius Tranquillus, Vita Tiberii: Kommentar, Würzburg (diss.). Vottero (1989): Dionigi Vottero (ed.), Seneca. Questioni Naturali, Torino.

Vottero (1998): Dionigi Vottero (ed.), Lucio Anneo Seneca. I frammenti, Bologna.

Walbank (1957): Frank W. Walbank, A Historical Commentary on Polybius I, Oxford.

Walker (1952): Betty Walker, The Annals of Tacitus. A Study in the Writing of History, Manchester.

Wallace-Hadrill (1983): Andrew Wallace-Hadrill, Suetonius. The Scholar and his Caesars, London.

Wallace-Hadrill (2005): Andrew Wallace-Hadrill, “Mutatas Formas: the Augustan Transformation of Roman Knowledge”, in: Karl Galinsky (ed.), The Cambridge Companion to the Age of Augustus, Cambridge, 55-84.

Walser (1951): Gerold Walser, Rom, das Reich und die fremden Völker in der Geschichtsschreibung der frühen Kaiserzeit. Studien zur Glaubwürdigkeit des Tacitus, Baden-Baden.

Walther (1993): Gerrit Walther, Niebuhrs Forschung, Stuttgart.

Waltz (1990): René Waltz, Vie de Sénèque, Paris.

Wardle (1994): David Wardle, Suetonius' Life of Caligula: A Commentary, Brussels.

Wardle (2014): David Wardle (ed.), Suetonius: Life of Augustus, Oxford.

Weinrib (1968): Ernest J. Weinrib, The Spaniards in Rome from Marius to Domitian, Cambridge (diss.).

Weinrib (1990): Ernest J. Weinrib, The Spaniards in Rome from Marius to Domitian, New York/London. 
Welch (2015): Kathryn Welch (ed.), Appian's Roman History: Empire and Civil War, Swansea. Welch (2019): Kathryn Welch, “Appian and Civil War: a History without an Ending”, in: Lange/Vervaet (2019a), 439-466.

Wellesley (1954): Kenneth Wellesley, “Can you trust Tacitus?”, in: G\&R1, 13-35.

Westall (2013): Richard Westall, “The Relationship of Appian to Pollio: A Reconsideration”, in: ARID 38, 95-123.

Westall (2015): Richard Westall, “The Sources for the Civil Wars of Appian of Alexandria”, in: Welch (2015), 125-167.

Westerburg (1882): Eugen Westerburg, “Lucan, Florus und Pseudo-Victor”, in: RhM 37, 35-49. Whitehorne (1969): John E. G. Whitehorne, “The Elder Seneca: A Review of Past Work”, in: Prudentia 1, 14-27.

Whitton (2019): Christopher L. Whitton, The Arts of Imitation in Latin Prose: Pliny's Epistles/ Quintilian in Brief, Cambridge.

Wilkes (1972): John Wilkes, “Julio-Claudian Historians”, in: CW 65, 177-192, 197-203.

Wingo (1972): Elvis Otha Wingo, Latin Punctuation in the Classical Age, Berlin/New York.

Winkworth (1852²): Susanna Winkworth, The Life and Letters of Barthold George Niebuhr, vol. 2, London.

Winterbottom (1974): Michael Winterbottom (ed.), The Elder Seneca, Declamations, Cambridge. Winterbottom (2013): Michael Winterbottom, “De vita patris”, in: Damschen/Heil (2012), 695698.

Wirszubski (1950): Chaim Wirszubski, Libertas as a Political Idea at Rome during the Late Republic and Early Principate, Cambridge.

Wirth (2007): Gerhard Wirth, Katastrophe und Zukunftshoffnung. Mutmassungen zur zweiten Hälfte von Diodors Bibliothek und ihren verlorenen Büchern, Wien.

Wiseman (2010): Tim P. Wiseman, “The Two-Headed State: How Romans Explained Civil War”, in: Breed et all. (2010), 25-44.

Wiseman (2013): Tim P. Wiseman, The Death of Caligula, Liverpool.

Wójcik (1986): Maria Rita Wójcik, La Villa dei Papiri di Ercolano: contributo alla ricostruzione dell'ideologia della nobilitas tardorepubblicana, Roma.

Wolverton (1964): Robert E. Wolverton, "Speculum Caesaris”, in: Mary Frances Wood and Eugene Wood Davis (eds), Laudatores Temporis Acti: Studies in Memory of Wallace Everett Caldwell, Chapel Hill, 82-90.

Woodman (1966): Anthony J. Woodman, “Actium in Velleius”, in: Latomus 25, 564-566.

Woodman (1968): Anthony J. Woodman, "Sallustian Influence on Velleius Paterculus", in: Hommages à Marcel Renard I, Brussels, 785-799.

Woodman (1975a): Anthony J. Woodman, “Questions of Date, Genre, and Style in Velleius: Some Literary Answers", in: CQ 25, 272-306.

Woodman (1975b): Anthony J. Woodman, "Velleius Paterculus", in: Thomas A. Dorey (ed.), Empire and Aftermath: Silver Latin II, London, 1-25.

Woodman (1977): Anthony J. Woodman (ed.), Velleius Paterculus: the Tiberian Narrative (2.94131), Cambridge.

Woodman (1979): Anthony J. Woodman, "Self-Imitation and the Substance of History: Tacitus, Annals 1.61-5 and Histories 2.70, 5.14-15”, in: David West and Anthony J. Woodman (eds), Creative Imitation in Latin Literature, Cambridge, 143-155.

Woodman (1983): Anthony J. Woodman (ed.), Velleius Paterculus: the Caesarian and Augustan Narrative (2.41-93), Cambridge.

Woodman (1988): Anthony J. Woodman, Rhetoric in Classical Historiography, London. 
Woodman (1998): Anthony J. Woodman, Tacitus Reviewed, Oxford.

Woodman (2003): Anthony J. Woodman, "Poems to Historians: Catullus 1 and Horace, Odes 2.1", in: David Braund and Christopher Gill (eds), Myth, History and Culture in Republican Rome: Studies in Honour of T. P. Wiseman, Exeter, 191-216 [repr. in Woodman (2012), 121144].

Woodman (2006): Anthony J. Woodman, “Tiberius and the Taste of Power: The Year 33 in Tacitus", in: CQ 56, 175-189.

Woodman (2009): Anthony J. Woodman, “Introduction”, in: Anthony J. Woodman (ed.), The Cambridge Companion to Tacitus, Cambridge, 1-14.

Woodman (2010a): Anthony J. Woodman, “Aliena Facundia: Seneca in Tacitus”, in: Dominic H. Berry and Andrew Erskine (eds), Form and Function in Roman Oratory, Cambridge, 294307.

Woodman (2010b): Anthony J. Woodman, "Community Health. Metaphors in Latin Historiography", in: Papers of the Langford Latin Seminar 14, 43-61.

Woodman (2012): Anthony J. Woodman, From poetry to history: Selected Papers, Oxford.

Woodman (2015): Anthony J. Woodman, Lost Histories: Selected Fragments of Roman Historical Writers, Newcastle, [https://research.ncl.ac.uk/histos/documents/SV02WoodmanLost Histories.pdf].

Woodman (2017): Anthony J. Woodman (ed.), The Annals of Tacitus: Books 5 and 6, Cambridge.

Woodman/Martin (1996): Anthony J. Woodman and Ronald H. Martin (eds), The Annals of Tacitus: Book 3, Cambridge.

Wuilleumier/Le Bonniec (1962): Pierre Wuilleumier and Henri Le Bonniec (eds), M. Annaeus Lucanus: Liber Primus, Paris.

Yardley (2003): John C. Yardley, Justin and Pompeius Trogus. A Study of the Language of Justin's Epitome of Trogus, Toronto.

Yarrow (2006): Liv Mariah Yarrow, Historiography at the End of the Roman Republic, Oxford.

Yavetz (1999): Zvi Yavetz, Tiberio. Dalla finzione alla pazzia. Con un'appendice su Tacito: il trauma della tirannia, Bari.

Zanon Dal Bo (1986): Agostino Zanon Dal Bo (ed.), Seneca il Vecchio. Oratori e Retori II, Bologna.

Zecchini (1977): Giuseppe Zecchini, "Seneca il Vecchio fonte di Appiano?”, in: Aevum 51, 145148.

Zecchini (1982): Giuseppe Zecchini, “Asinio Pollione: dall'attività politica alla riflessione storiografica”, in: ANRW II.30.2, 1265-1296.

Zecchini (1987): Giuseppe Zecchini, Il Carmen de bello Actiaco. Storiografia e lotta politica in età augustea, Stuttgart/Wiesbaden.

Zecchini (1999): Giuseppe Zecchini, "Regime e opposizioni nel 20 d.C.: dal S.C. 'de Cn. Pisone patre' a Tacito”, in: Marta Sordi (ed.), Fazioni e congiure nel mondo antico, Milano, 309335.

Zecchini (2016): Giuseppe Zecchini, Storia della storiografia romana, Roma/Bari.

Zehnacker (1983): Hubert Zehnacker (ed.), Pline l'ancien: Histoire naturelle. Livre XXXIII, Paris. Zehnacker/Méthy (2015): Hubert Zehnacker and Nicole Méthy (eds), Pline le Jeune. Lettres II, Paris. 